\title{
Diversidade florística de Dioscoreaceae na Reserva Biológica do Alto da Serra de Paranapiacaba, Santo André, São Paulo, Brasil
}

\author{
Mizue Kirizawa ${ }^{1,4}$, Cecilia Carmen Xifreda ${ }^{2}$ e Jonathan Henrique da Silva ${ }^{3}$
}

Recebido: 22.07.2015; aceito: 27.01.2016

\begin{abstract}
Floristic diversity of Dioscoreaceae from Reserva Biológica do Alto da Serra de Paranapiacaba, Santo André, São Paulo State, Brazil). The present study aimed to investigate and analyze the floristic diversity of Dioscoreaceae from Reserva Biológica do Alto da Serra de Paranapiacaba, Santo André, in order to increase the knowledge of Dioscoreales flora of this conservation unity and of São Paulo State. The field trips were conducted from 1978 until 2014; specimens from herbaria B, BOTU, ESA, IAC, NY, R, RB, SP, SPF, and UEC were consulted. We confirmed the occurrence of eight species of Dioscorea L. from Atlantic Forest of Serra do Mar. Among them, D. sanpaulensis and D. trilinguis are already listed as endangered species in the Brazilian Flora Red Book. Dioscorea torticaulis should now be included in the book as well, as it is endemic and rare in the Reserva Biológica de Paranapiacaba. The identification key, descriptions, illustrations, taxonomic, geographic, and phenology comments are presented.
\end{abstract}

Keywords: Atlantic Forest, climbing plants, Dioscorea, flora, Serra do Mar

RESUMO - (Diversidade florística de Dioscoreaceae na Reserva Biológica do Alto da Serra de Paranapiacaba, Santo André, SP, Brasil). O objetivo do presente estudo é investigar e analisar a diversidade florística de Dioscoreaceae na Reserva Biológica do Alto da Serra de Paranapiacaba para aumentar o conhecimento florístico de Dioscoreales desta unidade de conservação e do Estado de São Paulo. As coletas na Reserva foram realizadas entre 1978 até 2014; consultados os espécimes dos herbários B, BOTU, ESA, IAC, NY, R, RB, SP, SPF e UEC. Confirmamos a ocorrência de oito espécies de Dioscorea L. da Floresta Atlântica da Serra do Mar. Destas, D. sanpaulensis e D. trilinguis já constam como espécies ameaçadas de extinção no Livro Vermelho da Flora do Brasil. Deve ser incluída agora a Dioscorea torticaulis, endêmica e rara na Reserva Biológica de Paranapiacaba. São apresentados a chave de identificação, descrições, ilustrações, comentários taxonômicos, geográficos e fenológicos.

Palavras-chave: Dioscorea, flora, Mata Atlântica, plantas trepadeiras, Serra do Mar

\section{Introdução}

Dioscoreaceae, juntamente com Burmanniaceae e Nartheciaceae, compõe atualmente a ordem Dioscoreales, com base em recentes análises de dados morfológicas e moleculares, conduzidos por Chase et al. (2000), Caddick et al. (1998, 2000, 2002 e 2002a) entre outros. Assim, após a reclassificação dos táxons, fazem parte de Dioscoreaceae os gêneros Dioscorea, Stenomeris, Tacca e Trichopus, com centro de diversidade genérica no sudeste da Ásia, sendo muito comum em áreas úmidas ou secas estacionais (Dahlgren et al. 1985), raras em regiões temperadas e alpinas (Caddick et al. 2002).
Dioscorea é o gênero com maior número de representantes no mundo, estimado em torno de 608 espécies (Govaerts et al. 2007); destas, 130 espécies (94 endêmicas) ocorrem no Brasil (Kirizawa et al. 2010) e, cerca de 38\% distribuem-se em áreas de Mata Atlântica (Kirizawa \& Xifreda 2009). No Estado de São Paulo, há registro de 50 espécies de Dioscorea que se distribuem preferencialmente na parte leste coberta por floresta ombrófila densa montana (Kirizawa \& Xifreda 2011).

O estudo sobre a Flora Fanerogâmica na Reserva Biológica do Alto da Serra de Paranapiacaba, Santo André, SP, possibilitou o registro de 1.006

1. Instituto de Botânica, Núcleo de Pesquisa Curadoria do Herbário de São Paulo, 01061-970 São Paulo, SP, Brasil

2. Instituto de Botánica Darwinion, Labardén 200, Casilla de Correo 22, San Isidro, Buenos Aires, Argentina

3. Instituto de Botânica, Núcleo de Pesquisa em Anatomia, 01061-970 São Paulo, SP, Brasil

4. Autor para correspondência: mkirizawa@uol.com.br 
espécies fanerogâmicas, distribuídas em 434 gêneros e 118 famílias; entre as quais a Dioscoreaceae (Kirizawa et al. 2010), representada por oito espécies de Dioscorea: D. bulbotricha Hand.-Mazz., D. marginata Griseb., D. monadelpha (Kunth) Griseb., D. sanpaulensis $\mathrm{R}$. Knuth, D. tauriglossum R. Knuth, $D$. torticaules R. Knuth e D. trilinguis Griseb. (Kirizawa et al. 2009). Dessas, quatro estão representadas por tipos, coletados nas décadas de 1910 e 1920 (Kirizawa et al. 2009). Duas espécies já foram alvo de pesquisas fisiológica e fitoquímica (Ladeira et al. 1992, Chu 1989); uma espécie, D. monadelpha (Kunth) Griseb., está sendo investigada em termos de estrutura foliar e floral. Mas, do ponto de vista taxonômico, sabe-se que várias espécies de Dioscorea apresentam problemas taxonômicos que requerem estudos mais detalhados de atualização nomenclatural e, também, novas coletas (Kirizawa \& Xifreda 2009, Kirizawa et al. 2010). Além disso, os sistemas subterrâneos e órgãos vegetativos aéreos de $D$. delicata $\mathrm{R}$. Knuth (possivelmente D. bulbotricha), e D. tauriglossum estão sendo investigados em termos de anatomia e bioquímica por Jonathan Henrique da Silva (com. pess.).

Com o presente estudo florístico, os autores têm como objetivo contribuir para melhor conhecimento da família Dioscoreaceae, ampliando a descrição original com inclusão de caracteres adicionais, sinônimos, novas coletas, ilustrações e observações taxonômicas, nomenclaturais, sobre distribuição geográfica e fenologia dos táxons; e, identificar as espécies ameaçadas de extinção visando sua preservação na Reserva Biológica de Paranapiacaba e no Estado de São Paulo.

\section{Material e métodos}

O local de estudo foi a Reserva Biológica do Alto da Serra de Paranapiacaba, situada no município de Santo André, distrito de Paranapiacaba, entre as coordenadas geográficas $23^{\circ} 46^{\prime} 00^{\prime \prime}-23^{\circ} 47^{\prime} 10^{\prime \prime} \mathrm{S}$ e $46^{\circ} 18^{\prime} 20^{\prime \prime}-46^{\circ} 20^{\prime} 40^{\prime \prime} \mathrm{W}$, portanto, na borda das escarpas da Serra do Mar e próxima da vila de Paranapiacaba, Estado de São Paulo (Kirizawa et al. 2009). Criada em 1909 por Hermann Friedrich Albrecht von Ihering, foi chamada de Estação Biológica do Alto da Serra ou Parque Cajuru; e, durante a gestão de Frederico Carlos Hoehne, a infraestrutura da Reserva foi implementada e sua diversidade conhecida também no exterior. Atualmente com 336 hectares, predomina vegetação secundária, com variações fisionômicas em função da topografia, solo e alterações antrópicas, como Mata alta, Mata baixa, Frutíceto, Frutíceto escuro e Campo sujo (Kirizawa et al. 2009, Sugiyama et al. 2009). No mesmo distrito, localiza-se o Parque Natural Municipal Nascentes de Paranapiacaba onde 46,88\% da Floresta Ombrófila Densa Montana, representada por vegetação secundária em estágio avançado de regeneração, abriga 90 espécies principalmente de arbóreas (Instituto Ekos 2006, Prefeitura do Município de Santo André 2008).

As atividades de coleta de Dioscoreaceae foram concomitantes com o levantamento das Fanerógamas da Reserva de Paranapiacaba realizado de 1978 a 1994. Posteriormente, coletas adicionais foram feitas em toda a Reserva até 2014, inclusive para estudo taxonômico de Dioscoreaceae. Na formação dessa coleção, contribuíram até 1978 vários botânicos como Frederico Carlos Hoehne, Gustavo Edwall, Augusto Gehrt, João Rodrigues Mattos (Kirizawa et al. 2009). A maior parte desse material está depositada no Herbário SP; no entanto, coleções de outros herbários foram consultadas, como as de B, BOTU, ESA, NY, $\mathrm{R}, \mathrm{RB}, \mathrm{SPF}$ e UEC.

Análise morfo-taxonômica das exsicatas e sua identificação com auxílio de bibliografia especializada permitiram as descrições dos táxons, a confecção das chaves, complementadas com registro in loco do hábito, das inflorescências e infrutescências, além das ilustrações; e a indicação de três espécies ameaçadas de extinção.

\section{Resultados e Discussão}

\section{Dioscoreaceae R. Br.}

Geófitas, rizoma ou tubérculo providos de amido e saponinas esteroidais; caule aéreo volúvel ou ereto, herbáceo, às vezes lenhoso, liso, aculeado ou espinescente. Folhas alternas ou opostas, lâmina inteira ou composta, venação primária campilódroma, pinada ou palmada, venação secundária reticulada, pecíolo com pulvinos em cada extremidade. Inflorescência axilar e/ou terminal, solitária ou em panícula, cimo, espiga ou racemo, simples ou ramificada. Flores epígenas, 1-sexuadas (Dioscorea) ou 2-sexuadas (Stenomeris, Tacca, Trichopus), actinomorfas; alvas, amarelo-pálidas, esverdeadas ou castanho-púrpuras, bracteoladas ou não; tépalas 6 , em dois verticilos, semelhantes ou diferentes entre si, livres ou unidas na base ou em tubo; estames (ou estaminódios) 3, 6 ou 3 estames alternando-se com 3 estaminódios, 
filetes livres ou unidos, parcial ou totalmente, anteras 2-tecas, rimosas, dorsifixas; pistilódio nulo, pequeno ou desenvolvido; ovário ínfero, 3-carpelar, 1-locular (Tacca) ou 3-locular (Dioscorea, Trichopus), óvulos 2 ou numerosos por lóculo, estiletes 3 ou colunar, 3-partido no ápice, cada ramo inteiro ou 2-furcado, 2-lobado, estrelado ou falconiforme. Fruto cápsula, trialada ou baga; semente alada ou globosa a prismático-reniforme; embrião pequeno, plúmula terminal ou subterminal, cotilédone desenvolvido.

Recente estudo baseado em análise de caracteres morfológicos e moleculares levaram à redefinição da família Dioscoreaceae e ordem Dioscoreales (Caddick et al. 2002). Entre os gêneros citados Dioscorea destaca-se pelo maior número de espécies no mundo (Govaerts et al. 2007).

Dioscorea L., Sp. P1., ed. 1: 1032. 1753.

Sinônimos relevantes: Borderea Miégev., Bull. Soc. Bot. France 13: 374. 1866; R. Knuth in Engl., Pflanzenr. 4.43: 327. 1924.

Epipetrum Phil., Anales Univ. Chile 22: 448. 1862; Phil., Linnaea, 33: 253. 1864; R. Knuth in Engl., Pflanzenr. 4. 43: 327. 1924.

Higinbothamia Uline, Publ. Field Columbian Mus., Bot. Ser. 1(5): 414, t. 22. 1899; R. Knuth in Engl., Pflanzenr. 4. 43: 325. 1924.

Nanarepenta Matuda, Anales Inst. Biol. Univ. Nac. México 32: 143.
Rajania L., Sp. Pl., ed. 1: 1032. 1753; R. Knuth in Engl., Pflanzenr. 4. 43: 330. 1924.

Tamus L., Sp. Pl., ed. 1: 1028. 1753; R. Knuth in Engl., Pflanzenr. 4. 43: 340. 1924.

Trepadeiras, dióicas ou monóicas; sistema subterrâneo tuberiforme ou rizomatoso. Caule volúvel, dextrorso ou sinistrorso, geralmente herbáceo. Folhas alternas, às vezes opostas; lâmina inteira a lobada, 3-11 nervuras primárias; pecíolo com genículo basal às vezes transformado em espinho. Inflorescência estaminada racemo simples ou com cimos, panícula ou espiga; inflorescência pistilada espiga; raque angulada, alada; pedúnculo às vezes quase séssil. Flores unissexuadas, homoclamídeas; perigônio trímero, tubo e tépalas de comprimento variável. Flores estaminadas solitárias, em glomérulos ou cimo; estames 3 ou 6; estaminódios 3 ou ausentes. Flores pistiladas sésseis; estaminódios 3, 6 ou ausentes; estiletes livres ou piramidal; ovário 3-locular; óvulos 2 por lóculo. Cápsula 3-alada; sementes com ala circular ou posterior.

As Dioscoreaceae da Reserva Biológica do Alto da Serra de Paranapiacaba estão representadas apenas pelo gênero Dioscorea e suas oito espécies: D. altissima Lam., D. bulbotricha Hand.-Mazz., D. marginata Griseb., D. monadelpha (Kunth) Griseb., D. sanpaulensis R. Knuth, D. tauriglossum R. Knuth, D. torticaulis R. Knuth e D. trilinguis Griseb., distribuídas em três Seções do subgênero Helmia (Kunth) Benth. e três do Eudioscorea Pax.

Chaves para as espécies de Dioscorea

1. Caule aéreo triangular a quadrangular, angulado nos entrenós basais, cilíndrico nos ramos jovens; acúleos triangulares, achatados, particularmente nos nós inferiores e base do pecíolo, lignificados e aguçados na base do caule 1. D. altissima

1. Caule aéreo subcilíndrico a cilíndrico, sulcado, sulcado-angulado, estriado; acúleos ausentes

2. Flores estaminadas com 6 estames férteis

3. Inflorescência estaminada espiga, flores em gromérulos, perigônio rotáceo, filetes mais curtos que $0,5 \mathrm{~mm}$ compr.; flor pistilada sem estaminódios, estigmas lobados; cápsula obovada, 3-5,5 cm compr., ápice emarginado; ala seminal hemi-esférica

3. D. marginata

3 Inflorescência estaminada racemosa, flores cimosas, pediceladas, perigônio não rotáceo, filetes

0,5-1 mm compr.; flor pistilada com 6 estaminódios, estigmas não lobados; cápsula elíptica, elípticooblonga, oblonga ou lanceolada, 1,1-4,5 cm compr., ápice não emarginado; ala seminal posterior 4. Tubérculo piriforme; estames exsertos; cápsula 1,1-2 cm compr.; ala seminal posterior elípticooblonga 5. D. sanpaulensis

4. Tubérculo não piriforme; estames inclusos; cápsula 2-4,5 cm compr.; ala seminal posterior oblonga a lanceolada

5. Planta com tricomas tectores bulbosos; lâmina foliar 7-9 nervuras; flores estaminadas não em cimo escorpióide, perigônio globoso-campanulado a urceolado 2.D. bulbotricha

5. Planta sem tricomas tectores bulbosos; lâmina foliar 5-7 nervuras; flores estaminadas em cimo escorpióide, perigônio campanulado 6. D. tauriglossum 
2. Flores estaminadas com 3 estames férteis

6. Filetes unidos em coluna carnosa; flor pistilada com 3 estiletes uncinados; monóica 4. D. monadelpha

6. Filetes livres; flor pistilada com estilete colunar 3-partido no ápice; dióica

7. Perigônio radiado; flores estaminadas em gromérulos, estaminódios ausentes, pistilódio nulo; flor pistilada sem perigônio estipitado; sistema subterrâneo tuberiforme . 7. D. torticaulis

7. Perigônio hipocrateriforme; flores estaminadas em racemo ou panícula, estaminódios 3, pistilódio cônico; flor pistilada com perigônio estipitado; sistema subterrâneo rizomatoso 8.D. trilinguis

1. Dioscorea altissima Lam., Encycl. 3: 231. 1789; R. Knuth in H.G.A. Engler (ed.), Pflanzenr, IV, 43 (87): 81, fig. 18, A-D. 1924.

Dióica; sistema subterrâneo rizomatoso. Caule aéreo dextrorso, lenhoso, triangular a quadrangular, angulado nos entrenós basais, cilíndrico nos ramos jovens, 1-8 mm larg., escabroso, acúleos triangulares, achatados, particularmente nos nós inferiores e base do pecíolo, lignificados e aguçados na base do caule. Folhas alternas a opostas; lâmina $4-16,5 \mathrm{~cm}$, compr., 2-10,5 cm larg, triangular-elíptica, obovada a quase orbicular, ápice longo acuminado, caudado ou cuspidado, base quase retusa nas folhas jovens, nas adultas sagitiforme ou com sinus $0,5-3,5 \mathrm{~cm}$ de profundidade, separando lobos arredondados, 7-11 nervuras, as laterais externas bifurcadas próximo da base, salientes na face abaxial, as secundárias quase paralelas, membranácea a quase coriácea, pontuada de vermelho, rafídeos numerosos, às vezes pelos glandulares e tectores na face abaxial, verde amarelada a verde escura, quando jovem avermelhada; pecíolo 1,5-9 cm compr., alargado na base. Inflorescência estaminada em espiga, 1-2 por axila, geralmente simples, 6-14 cm compr., pedúnculo 1,5-2,5 cm compr.; bractéolas ovadolanceoladas, longamente acuminadas, glabras na face adaxial. Flores estaminadas sésseis, esverdeadas, avermelhadas quando secas; perigônio campanulado, profundamente partido, tubo curto; tépalas 1,2-1,3 mm compr., 0,5-0,6 mm larg., patentes a recurvadas, elípticas a oblongas, agudas a obtusas no ápice, 1-nervura, pintalgadas de vermelho, glabras em ambas as faces; estames 6 , livres, fixos na base dos lobos do perigônio, inclusos, filetes $0,5-0,6 \mathrm{~mm}$ compr., achatados, ereto-patentes, encurvados no terço basal, anteras introrsas, ca. 0,1 mm de compr., ovais; pistilódio crasso, tricúspide no ápice, ca. $0,5 \mathrm{~mm}$ de compr. Inflorescência pistilada em espiga, simples, 1 por axila, 6-12 cm compr.; pedúnculo 2-3 cm compr.; bractéola 1. Flores pistiladas sésseis, avermelhadas; perigônio profundamente partido, tépalas 1-2 mm compr., 0,4-0,5 mm larg., oblongas, ereto-recurvadas, 1-nervura; estaminódios 6 , anteríferos, subsésseis; ovário 2,5-3 mm compr., avermelhado, rugoso; estilete colunar, crasso, 0,6-1 mm compr., 3-partido no ápice, cada ramo 2-labiado. Infrutescência 7-22 cm compr. Cápsula 1,7-2,7 cm compr., 0,7-1,5 cm larg., elípticooblonga, ápice apiculado, base obtusa, pruinosa, verde-avermelhada ao longo do septo, quase lenhosa e castanho-avermelhada quando seca, bordo levemente elevado; sementes $0,6-1,9 \mathrm{~cm}$ compr., $0,3-0,4 \mathrm{~cm}$ larg., ala posterior oblonga.

Material examinado: BRASIL. São Paulo: Santo André, Reserva Biológica do Alto da Serra de Paranapiacaba, estéril, região de areais, 3-V-2002, $M$. Kirizawa \& R.P. Romanini 3449 (SP).

Material adicional examinado: BRASIL. São PAULO: Cananéia, fl. §̂, 13-IV-1987, M. Kirizawa \& D.M. Vital 1839 (SP); idem, Parque Estadual da Ilha do Cardoso, fr., 21-VI-1989, M. Kirizawa 2250 (SP); Iporanga, fl. \%, fr., 21-IV-1987, M. Kirizawa 1844 (SP); Bertioga, cult. São Paulo, fl. ふૈ, 18-I-1991, M. Kirizawa 2385 (SP); idem, cult. São Paulo, fr., 1-VI-1999, M. Kirizawa 3382 (SP); idem, cult. São Paulo, est., 8-I-2004, M. Kirizawa 3457 (SP).

Ocorre em Antilhas, Martinica, Tobago, Panamá, Guianas, Brasil, Paraguai e Argentina (Barroso et al. 1974). No Brasil, é encontrada nos Estados das Regiões Sudeste, Sul e Centro-Oeste, além da Bahia e Amazonas. Nas aldeias indígenas do Baixo Amazonas, a espécie é cultivada em hortas e roças familiares para uso das túberas como alimento (Knupp \& Lorenzi 2014). No entanto, o manejo agroecológico da espécie visando o uso mais amplo dessas estruturas com finalidade alimentícia requer aprofundamento da pesquisa (Knupp \& Lorenzi 2014). Em São Paulo, D. altissima habita principalmente a planície litorânea e Floresta Ombrófila Densa de Encosta (Kirizawa \& Romanini 2003, Kirizawa \& Xifreda 2009), onde foi encontrada com flores estaminadas em janeiro, abril e maio, flores pistiladas em abril e frutos desenvolvidos em abril e junho. Na Reserva de Paranapiacaba, tem sido observada comumente sem flores ou frutos, por isso, a descrição foi baseada nas coleções de outras regiões do Estado de São Paulo. Todavia, caracteres 
como acúleos triangulares, achatados, particularmente nos nós inferiores do caule e na base do pecíolo, além do ápice foliar longamente acuminado, permitem fácil reconhecimento do táxon.

Ilustração: Kirizawa \& Romanini (2003).

2. D. bulbotricha Hand.-Mazz. in Denksch. Kais. Akad. Wiss. Wien, Math.-Naturw K1. 79: 221, f.8-9. 1908.

Figuras 1-11

Sinônimo: Dioscorea delicata R. Knuth, in H.G.A. Engler (ed.) Planzenr. IV, 43 (87)): 61. 1924.

Dióica, ca. $3 \mathrm{~m}$ alt. ou mais, com tricomas tectores bulbosos; sistema subterrâneo tuberiforme, ovado ou levemente lobado. Caule sinistrorso, subcilíndrico, sulcado, 1-3 mm larg., áspero ao tato, entrenós basais áfilos, verdes a vináceos, densamente cobertos por tricomas tectores simples, alargados na base, alvos, escassos tricomas glandulares; acúleos ausentes. Folhas alternas; lâmina 4-14(-18) cm compr., 2,5-10(-13,5) cm larg., ovada a ovado-lanceolada, ápice abrupta a longamente acuminado, encurvado lateralmente, base cordada, às vezes quase sagitada nos nós basais, margem não cartilagínea, levemente ondulada, 7-9-nervuras, nervuras laterais 1-furcadas, rígido-membranácea, membranácea a quase papirácea nos ramos mais jovens, verde-escura na face adaxial, mais clara na abaxial ou verde clara nos ramos superiores, densamente pontuada de vermelho, levemente pubescente na base da lâmina; pecíolo 1,5-6,5(-9) cm compr., verde a vináceo, genículo basal persistente nos nós basais áfilos. Inflorescência estaminada racemo, 1-2 por axila, simples, às vezes ramificada próximo da base, $3-18 \mathrm{~cm}$ compr., ereto pendente, com numerosos cimos de 0,5-1 cm compr.; pedúnculo 0,2-2 cm compr.; bractéolas 2, ovadooblongas, longamente acuminadas, glabras, com ou sem glândulas rubiginosas. Flores estaminadas 1-5 por cimo, não escorpioide, verde-amareladas, pintalgadas de vermelho; pedicelo 0,7-2,5 mm compr.; perigônio globoso-campanulado, quase urceolado, 1,5-2 $\mathrm{mm}$ compr.; tépalas 0,6-0,7 mm compr., 0,4-0,6 mm larg., eretas, levemente reflexas, elípticas, agudas a obtusas no ápice, 1-nervura, carnosas in vivo; estames 6, livres, fixos na base do tubo do perigônio, inclusos; filetes $0,4-0,5 \mathrm{~mm}$ compr., menores que o tubo, mais largos na base, eretos, levemente justapostos na metade inferior, recurvados no terço apical, anteras extrorsas, diminutas, ca. 0,1 mm compr., ovais, amarelo-claras; pistilódio pequeno, cônico, tripartido no ápice. Inflorescência pistilada espiga, simples, 1-2 (-3) por axila, (5-)7-10,5(-20) cm compr., raque angulada, com pelos tectores e glandulares dispersos; pedúnculo 3-4,5 cm compr.; bractéolas 2, desiguais, ovado-oblongas, longamente acuminadas, pontos rubiginosos dispersos. Flores pistiladas sésseis, verdeamareladas, 0,5-1,3 cm distantes entre si; perigônio globoso-campanulado, ca. $3 / 4$ partido; tépalas $1-1,1 \mathrm{~mm}$ compr., 0,4-0,6 mm larg., elípticas, eretas, levemente encurvadas no ápice, 1-nervura, pontuadas de vermelho; estaminódios 6, anteríferos; ovário 3-4 mm compr., verde a verde-avermelhado, glabrescente, estilete colunar piramidal, ca. 0,8 mm compr., 3 -partido no ápice, bifurcado, ramos divergentes falconiformes. Cápsula (2-)2,5-4,0 (-4,5) cm compr., 1,1-1,5 cm larg., oblonga ou lanceolada, ápice agudo, base obtusa a retusa, cartácea, castanho-avermelhada; sementes 1,8-2 cm compr., ala posterior oblonga.

Material selecionado examinado: BRASIL. S̃̃o Paulo: Santo André, Reserva Biológica do Alto da

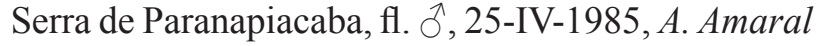
Jr. et al. 51 (BOTU, SP); fr., 16-II-2002, R.S. Bianchini et al. 1503 (SP); fl. o, fr., 5-6-X-1987, S.M. Carmello et al. 41 (BOTU, SP); fl. Ô, 18-X-1983, A. Custodio Filho 1684 (SP); fl. \%, fr., 29-XI-1983, A. Custodio Filho 1946 (SP); fl. Õ, 28-VII-1983, A. Custodio Filho \& C.B. Toledo 1386, (SP); fl. q, fr., 27-VIII-1980, E. Forero et al. 7648 (SP); fr., 9-VII-1925, A. Gehrt. s.n. (SP22444); fl. ô, 9-VII-1921, F.C. Hoehne s.n. (SP5715, isotipo); fr., 26-XI-1980, M. Kirizawa 557 (SP); plântulas 3 meses, 4-IV-1983, M. Kirizawa 917 (SP); fl. Ô, 11-IX-1984, M. Kirizawa 1289 (SP); fl. Ō, 14-VIII-1984, M. Kirizawa \& T.P. Guerra 1250 (SP); 今̂, 14-VIII-1984, M. Kirizawa \& E.A. Lopes 1252 (SP); fr., 24-III-1995, M. Kirizawa \& E. Mariano Neto 2964 (SP); fl. ô, fl. o+, fr., 20-IX-1983, M. Kirizawa \& M. Sugiyama 1080, 1081 (SP); fl. , fr., 29-IX-1988, M. Kirizawa \& M. Sugiyama 2072, 2075 (SP); fl. ô, 3-VIII-1979, M. Kirizawa et al. 433 (SP); fl. Ô, 2-VIII-1979, M. Kirizawa et al. 461 (SP); fl. Ô, 3-VIII-1979, M. Kirizawa et al. 471, 474 (SP); fl. + , fr., 20-XI-1981, M. Kirizawa et al. 577 (SP); fr., 4-V-1982, M. Kirizawa et al. 772 (SP); fl. ô, 6-X-1984, M. Kirizawa et al. 1323 (SP); fl. ô, 19-VI-1950, M. Kuhlmann 2845 (SP); fl. क , 15-VI-1951, M. Kuhlmann 2846 (SP); fr., 26-XI-1980, E.A. Lopes et al. 70

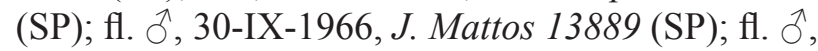
26-XI-1980, N.A. Rosa \& J.M. Pires 3893 (SP); fr., 27-X-1980, N.A. Rosa \& J.M. Pires 3954 (SP); fl. ô, fr., 12-VI-1984, M. Sugiyama \& E.A. Lopes 531, 532 (SP); fl. ô, 28-VII-1983, C.B. Toledo \& A. Custodio 


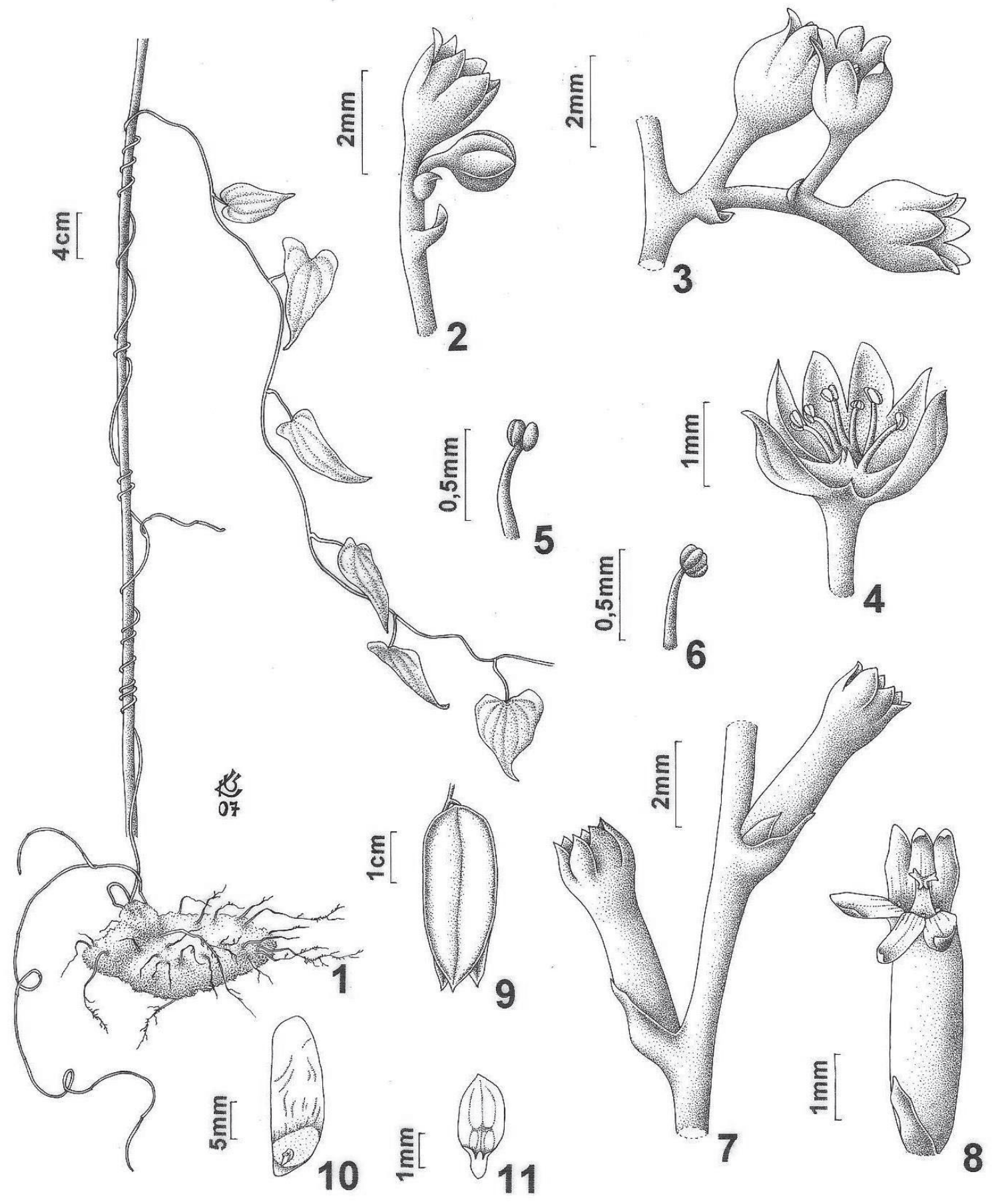

Figuras 1-11. Dioscorea bulbotricha Hand.-Mazz. 1. Planta com tubérculo. 2. Inflorescência estaminada. 3. Cimo com flores estaminadas. 4. Flor estaminada dissecada. 5-6. Estames, em vista abaxial e adaxial. 7. Fragmento de inflorescência pistilada. 8. Flor pistilada. 9. Fruto. 10. Semente. 11. Embrião (1. M. Kirizawa 2271, 2. F.C. Hoehne s.n. (SP5715), 3-6: M. Kirizawa et al. 461, 7-8. M. Kuhlmann 2846, 9-11. M. Kirizawa et al. 577).

Figures 1-11. Dioscorea bulbotricha Hand.-Mazz. 1. Plant with tubercule. 2. Staminate inflorescence. 3. Cyme of staminate flowers. 4. Dissected staminate flower. 5-6. Stamens, abaxial and adaxial . 7. Pistillate inflorescence fragment. 8. Pistillate flower. 9. Fruit. 10. Seed. 11. Embryo (1. M. Kirizawa 2271, 2. F.C. Hoehne s.n. SP5715, 3-6. M. Kirizawa et al. 461, 7-8. M. Kuhlmann 2846, 9-11. M. Kirizawa et al. 577). 
Filho 25 (SP); São Paulo, tubérculo da Reserva Biológica de Paranapiacaba cultivado no Instituto de Botânica, fr., 1-VI-1990, M. Kirizawa 2271 (SP); fl. ô, 10-VIII-2001, M. Kirizawa 3446 (SP).

Ocorre nos Estados de São Paulo. Paraná e Santa Catarina, na Serra do Mar, a 500-800 m de altitude. Na Reserva de Paranapiacaba, é observada particularmente ao longo de trilhas que atravessam a Floresta Ombrófila Densa sobre encostas íngremes, como a Washington Luiz, Frederico von Martius, Jean Massart e Adolpho Lutz. O tubérculo situa-se a menos de $10 \mathrm{~cm}$ de profundidade; contém mais de $60 \%$ do peso seco de resíduos fibrosos, amido inferior a $8 \%$ e menos de $0,3 \%$ de sapogeninas esteroidais, compostos de importância medicinal, além de proteínas e carboidratos solúveis (Chu 1989). Coletada com flores estaminadas de abril a novembro, mais intensamente entre agosto e novembro; as pistiladas entre junho e dezembro, em especial de agosto a outubro. A frutificação começa em agosto, atinge pleno desenvolvimento em novembro e dezembro, cada ramo com 1 a 9 frutos maduros; os frutos secos em maio e junho. Cada infrutescência pode apresentar de 1 a 9 frutos desenvolvidos.

Handel-Mazzetti (1908) descreveu a $D$. bulbotricha, com base no exemplar masculino coletado no Alto da Serra, Estado de São Paulo, em 1901 por Wettstein \& Schiffner. Esses botânicos, muito provavelmente devem ter utilizado a ferrovia São Paulo Railway Co. (atual RFFSA ramal SantosJundiaí) e descido na Estação Alto da Serra, Vila de Paranapiacaba, adjacente à Estação Biológica Alto da Serra (São Paulo 1990, Kirizawa et al. 2009). Nessas localidades, é comum a ocorrência de $D$. bulbotricha provida de tricomas setuliformes curtos e de base bulbosa, principalmente nos ramos inferiores e superiores mais jovens bem como no pecíolo. No entanto, essas características também foram observadas no isotipo do exemplar masculino de D. delicata coletado em 1921 por F.C. Hoehne (SP5715) e no material examinado pelos autores deste estudo, inclusive plantas in loco ocorrentes na borda do Planalto Paulistano da Serrania Costeira. As coletas efetuadas possibilitaram a descrição pela primeira vez do exemplar feminino e do fruto bem como a existência de variação de dimensões da folha no mesmo exemplar. As demais características descritas para as duas espécies, além do exame da fotocópia do tipo de $D$. bulbotricha e isotipo de $D$. delicata, não deixam dúvida quanto à necessidade de sinonimização desta última, com prioridade para a primeira descrita em 1908. Todavia, espera-se que estudos anátomo-bioquímicos em desenvolvimento no Instituto de Botânica forneçam subsídios robustos para atualização nomenclaltural das espécies citadas. Ambas diferem de D. ovata Vell. por esta apresentar flor estaminada infundibuliforme ou campanulada, ausência de pistilódio, forma e dimensões da cápsula.

3. Dioscorea marginata Griseb., Fl. bras. 3(1):37. 1842.

Figuras 12-18

Sinônimos: Smilax spicata Vell., Fl. Flum. X, tab.112., texto: 423. 1831 (1881).

Dioscorea albinervia R. Knuth in H.G.A. Engler (ed.), Pflanzenr. IV, 43: 74. 1924.

Dioscorea pallidinervia R. Knuth in H.G.A. Engler (ed.), Pflanzenr. IV, 43: 75. 1924.

Dioscorea spicata (Vell.) Pedralli, Bol. Bot. Univ. São Paulo, São Paulo, 20: 111. 2002.

Dióica, glabra; sistema subterrâneo tuberiforme. Caule dextrorso, 1-2 mm larg., entrenós 6,5-16 cm compr., sulcado-angulado, fibroso, com numerosos riscos e pontos rubiginosos; acúleos ausentes. Folhas alternas; lâmina 4,4-14,5 cm compr., 1,5-6,5 cm larg., elíptica a oblonga, às vezes largamente ovada, ápice curtamente acuminado ou apiculado, base aguda a obtusa, margem cartilagínea, 3-5-nervuras, cartácea a membranácea, às vezes subcoriácea, salpicada por numerosos pontos rubiginosos; pecíolo $1,5-3,5 \mathrm{~cm}$, sulcado fibroso, levemente alado nas margens, genículo basal alargado. Inflorescência estaminada espiga, 1 por axila, simples ou ramificada na base, 17-18,5 cm compr., ereto-pendente, raque e pedúnculo angulados, pontuados de vermelho, glomérulos 1-4-flora, distantes entre si 0,2-1 cm; pedúnculo 0,7-1 cm compr.; bractéolas ovado-conchiformes a oblongas, ambas longamente acuminadas, 1-nervura, pintalgadas de vermelho. Flores estaminadas sésseis, esverdeadovináceas; perigônio rotáceo, tubo $1 / 4$ do comprimento dos lobos, pontuado de vermelho; tépalas 1,5-2 mm compr., 0,5-0,7 mm larg., ovadas, ápice agudo a obtuso, 1-nervura, esverdeadas com base vinácea; estames 6 , livres, filetes mais curtos que $0,5 \mathrm{~mm}$ compr., encurvados, fixos na base do tubo, anteras globosas, pequenas, deiscência voltada para cima; pistilódio triangular, 3-partido no ápice, pequeno. Inflorescência pistilada espiga, 1 por axila, simples, raque angulada, mais longa que o pedúnculo. Flores pistiladas sésseis, vináceas; perigônio cupuliforme, 


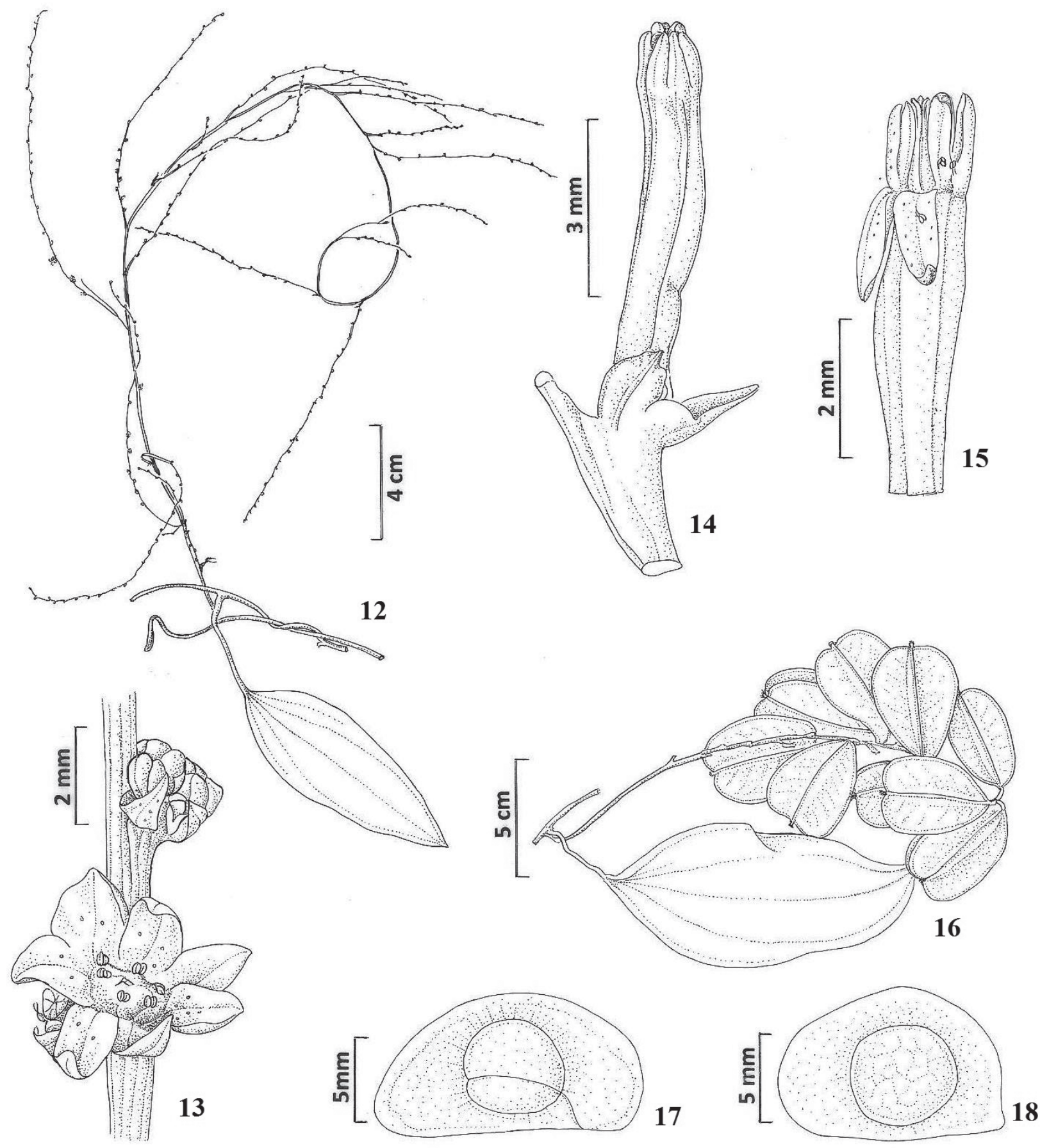

Figuras 12-18. Dioscorea marginata Griseb. 12. Ramo com folha e inflorescências estaminadas. 13. Botões e flores estaminadas. 14. Flor pistilada. 15. Detalhe do perigônio da flor pistilada. 16. Infrutescência. 17-18. Semente (12-13. S.J.G. Silva et al. 262, 14-15. E.L.M. Catharino 1092, 16-18. F.C. Hoehne s.n. SP31762).

Figures 12-18. Dioscorea marginata Griseb. 12. Branch with leaf and staminate inflorescences. 13. Buds and staminate flowers. 14. Pistillate flowers. 15. Detail of perianth pistillate flower. 16. Infructescence. 17-18. Seeds. 18. (12-13. S.J.G. Silva et al. 262 , 14-15. E.L.M. Catharino 1092, 16-18, F.C. Hoehne s.n. SP 31762). 
segmentos em grande parte livres; tépalas $0,6-0,9 \mathrm{~cm}$ compr., ca. $1 \mathrm{~cm}$ larg., ereto-encurvadas, ovadas, ápice agudo, 1-nervura, papiráceas; estaminódios ausentes; estilete colunar piramidal, ca. 0,5 mm compr., tripartido no ápice, bífido, estigmas lobados; ovário desenvolvido em fruto, $0,5 \mathrm{~cm}$ compr., avermelhado. Infrutescência 16-33 cm compr., pedúnculo $3-9 \mathrm{~cm}$ compr. Cápsula 3-5,5 cm compr., 3,3-4,0 cm larg., obovada, ápice emarginado, coriácea; sementes 1,2-1,5 cm compr., ca. 0,7 cm larg., hemi-esféricas, mais largas nas extremidades.

Material examinado: BRASIL. São Paulo: Santo André, Reserva Biológica do Alto da Serra de Paranapiacaba, fl. ô, 16-XI-1991, S.J. Gomes da Silva et al. 262 (SP).

Material adicional examinado: BRASIL. SÃo PAULO: Piracicaba, fl. , fr., 12-VIII-1987, E.L.M. Catharino 1092 (SP, ESA); São Miguel Arcanjo, próximo ao Parque Estadual Carlos Botelho, na beira da rodovia SP 139, São Miguel Arcanjo - Sete Barras, estéril, 24-IX-1992, M. Kirizawa s.n. (SP 474883); São Paulo, Parque Estadual das Fontes do Ipiranga, fr., 4-V-1934, F.C. Hoehne s.n. (SP 31762).

Dioscorea marginata pode apresentar sistema subterrâneo tuberiforme bastante desenvolvido, como aquele observado e coletado em São Miguel Arcanjo, SP. No entanto, a espécie é difícil de ser encontrada, principalmente com flores pistiladas, dificultando sua caracterização mais detalhada. Cresce na Floresta Ombrófila Densa, preferencialmente na faixa litorânea dos Estados da Bahia, Rio de Janeiro e São Paulo. Neste Estado, em diversas localidades, exemplares com flores pistiladas e frutos foram coletados em maio e agosto; mas, na Reserva de Paranapiacaba, o táxon portando flores estaminadas foi encontrado em dezembro.

Andreata (1980) verificou que a tábula 111 do volume 10 da Flora Fluminensis ilustra efetivamente a Smilax spicata Vell. e a tábula 112, juntamente com a descrição correspondente, à Dioscorea marginata Griseb., táxon da família Dioscoreaceae. Apesar de nomen ambiguum aplicado a duas espécies diferentes por Vellozo, a referida especialista em Smilacaceae manteve Smilax spicata como uma homenagem a Vellozo, designando o exemplar masculino ilustrado na tábula 111 em 1831 (1827) pelo referido botânico como lectótipo. Foram analisadas a tábula 112 e a descrição de Vellozo $(1827,1881)$ e comparadas com as coleções de $D$. marginata Griseb., que nos levou a concluir também que efetivamente o material de Vellozo ilustrado na tábula 112 refere-se à $D$. marginata, espécie descrita por Grisebach (1842), comprovando assim a observação de Andreata (1980, 1997). Por extensão, a validade do táxon $D$. spicata (Vell.) Pedralli (Pedralli 2002) é questionada, tendo Couto (2010) proposto com nom. illeg. A análise das descrições e dos tipos de Dioscorea albinervia R. Knuth e $D$. pallidinervia $\mathrm{R}$. Knuth, ambas coletadas na Serra do Mar, estado do Paraná, mostra afinidades estreitas com $D$. marginata, podendo incluí-las nesta última espécie, concordando, assim, com Couto (2010).

4. D. monadelpha (Kunth) Griseb., Vidensk. Meddel. Dansk. Naturhist. Foren. Kjobenhavn: 164. 1875.

Sinônimos: Helmia monadelpha Kunth, Enum. Pl.; 421.1850 .

Helmia monadelpha Kunth, Enum. Pl. V: 421. 1830 (Typus: Sellow 55 (lectotipo B).

Dioscorea monadelpha (Kunth) Pax, in H.G.A.Engler u. Prantl., Pflanzenf. 2(5): 133. 1888.

Dioscorea similis R. Knuth, Spec. Nov. Regni Veg. 21: 78.1925 .

Dioscorea longirachis R. Knuth, Fedde Repert. Spec. Nov. Regni Veg. 30: 159. 1932.

Monóica, delicada; sistema subterrâneo tuberiforme, discoide. Caule dextrorso, sulcadoangulado, ca. $1 \mathrm{~mm}$ larg., verde, salpicado de numerosas glândulas rubiginosas. Folhas alternas; lâmina 3,5-15 cm compr., 1,5-9 cm larg., triangularovada a sagitiforme, ápice longamente acuminado, sinus basal $1,5-3,5 \mathrm{~cm}$ de profundidade, auriculada a côncavo às vezes deltoide invertido, separando lobos basais arredondados, 9-nervuras, as externas trifurcadas próximo da base, geralmente membranácea a rígido-membranácea, discolor, numerosos rafídeos, tricomas glandulares e tectores simples, principalmente na face abaxial e na região de saída das nervuras primárias; pecíolo 1,5-5,5 cm compr., ca. 0,5 mm larg., canaliculado, genículo basal com pelos glandulares esparsos. Inflorescência estaminada racemo simples, 1-2 por axila, às vezes ramificada próxima da base, 5,5-25(-33) cm compr.; raque e pedúnculo sulcado-angulados, alas escabrosas; pedúnculo 2,5-5 cm compr.; bractéolas 2, a maior oblonga, a menor linear. Flores estaminadas isoladas em cada nó floral, ca. $7 \mathrm{~mm}$ diâm., verde clara, pedicelo 1-3 mm compr., com tricomas glandulares esparsos; perigônio campanulado, 3-4 mm compr., tubo com tricomas glandulares rubiginosos; tépalas desiguais, 
2,5-4 mm compr., 0,6-1 mm larg., unidas no terço basal, lanceolado-oblongas a oblongas, ápice agudo, 3-nervuras, estames 3, unidos em coluna estaminal 1,5-2 mm compr., cilíndrica, levemente trígona, carnosa, atro-purpúrea, com tricomas glandulares, 3-tida no ápice, cada segmento com antera coccínea, extrorsa. Inflorescência pistilada espiga, simples, 1 por axila; 6-12(-19) cm compr., raque angulada; pedúnculo 5-12 cm compr.; bractéolas 2, a maior acuminada e a menor subulada. Flores pistiladas sésseis, verdes; perigônio campanuliforme, patentes na ântese; tépalas ca. $2 \mathrm{~mm}$ compr., ca. $1 \mathrm{~mm}$ larg., oblongas, às vezes com pontos rubiginosos, 3-nervuras; estaminódios ausentes, ovário 2-3mm compr., 3 estiletes uncinados. Cápsula 1,2-3 cm compr., 0,8-1,4 cm larg., elíptica a oblonga, ápice obtuso, base aguda a obtusa; sementes 1,2-1,4 cm compr., 0,3-0, 5cm larg., 3/4 representados por ala posterior elíptica a oblonga.

Material examinado: BRASIL. São Paulo: São Paulo, tubérculo coletado na Reserva Biológica de Paranapiacaba cultivado no Instituto de Botânica, fl. ô, 23-XII-1990, M. Kirizawa 2383 (SP); cultivado no Instituto de Botânica, fl. Õ, 3-IV-1995, M. Kirizawa 2971 (SP); Santo André, Reserva Biológica do Alto da Serra de Paranapiacaba, fl. ô, 22-V-1984, A. Custodio Filho 2461 (SP); fl. ô, fl. o, 2-XII-1993, M. Kirizawa 2853 (SP); fl. गे, 14-VIII-1984, M. Kirizawa \& T.P. Guerra 1246 (SP); fl. Ō, fr., 26-II-1985, M. Kirizawa \& T.P. Guerra 1377 (SP); fl. Ō, fr., 25-IX-1995, M. Kirizawa \& M.L. Kawasaki 3215 (SP); fl. Ô, fr., 14-VIII-1984, M. Kirizawa \& E.A. Lopes 1247 (SP); fl. o, 20-XI-1984, M. Kirizawa \& E.A. Lopes 1345 (SP); fl. Õ, fr., 15-IV-1986, M. Kirizawa \& E.A. Lopes 1597 (SP); fl. §̂, 28-II-1984, M. Kirizawa et al. 1157 (SP); fr., 28-IV-2006, R. Simão-Bianchini s.n. (SP385250). Dioscorea monadelpha ocorre nas Regiões Sudeste e Sul do Brasil. Em São Paulo, cresce na borda do Planalto Paulistano e em clareiras de floresta de restinga e floresta ombrófila densa da Serra do Mar. O sistema subterrâneo pode pesar quase $2,5 \mathrm{~kg}$. (Barroso et al. 1974). Após analise bioquímica, Chu (1989) verificou que os tubérculos apresentaram teores de amido superiores a $30 \%$ do peso seco e alta porcentagem de compostos não solúveis em água, em particular a hemicelulose. Na Reserva Biológica do Alto da Serra de Paranapiacaba, as flores estaminadas foram observadas de agosto a dezembro, fevereiro a junho, raramente de maio a julho, quando tem início o fenecimento da parte aérea da planta; as flores pistiladas, em menor número, florescem em agosto, dificilmente observadas no outono, entre maio e junho. Os frutos surgem entre agosto e novembro; quando amadurecem em maio e junho, as cápsulas deiscentes mostram bordo filiforme que se destaca do restante da ala. Xifreda (1989) reabilitou Dioscorea monadelpha (Kunth) Griseb. coletada no Sudeste do Brasil, identificou Dioscorea subhastata Vell. e seus sinônimos D. guaratinica Chodat \& Hassler e Dioscorea lagoasanta Kunth. Posteriormente, em 2003, Xifreda \& Kirizawa (2003) esclareceram a identidade correta de $D$. monadelpha e D. subhastata, ao registrarem as observações morfológicas, nomenclaturais e taxonômicas das duas entidades.

Ilustrações em Kirizawa \& Xifreda (2003).

5. D. sanpaulensis R. Knuth in H.G.A. Engler (ed.) Pflanzenr. IV,43 (87): 57. 1924.

Figuras 19-29

Dióica, glabra, ca. 1,5m alt.; sistema subterrâneo piriforme, 3-4,5 cm diâm., 2,5 cm alt., a $10-15 \mathrm{~cm}$ de profundidade. Caule aéreo sinistrorso, subcilíndrico, sulcado, 1-2,5 mm larg., entrenós 5-14 cm compr., rafídeos esparsos, verde a castanho-avermelhado, às vezes com bulbilhos aéreos; acúleos ausentes. Folhas alternas; lâmina 3,5-10 cm compr., 1,2-4,5 cm larg., ovadas a elípticas, ovado-lanceoladas a lanceoladas nos ramos superiores, ápice apiculado a acuminado, base cordiforme, levemente constrita, com sinus, às vezes quase retusa, margem cartilagínea, revoluta, 5-7-nervuras, as laterais 1-ramificada, tênues, rígido-membranácea, face adaxial verde-escura, abaxial verde-clara ou acinzentada, normalmente com pontos rubiginosos, glândulas ovais na base do limbo; pecíolo 0,5-3 cm compr., carnoso in vivo, estriado dorsalmente, verde a castanho-avermelhado. Inflorescência estaminada racemo, às vezes áfila na extremidade apical, 1-3 por axila, simples, ramificada próximo da base, 4-16(-21) cm compr., raque angulada, alada, com cimos, rafídeos esparsos; pedúnculo 0,5-3,5(-5) cm compr.; bractéolas 2, ovadas a elípticas, acuminadas, às vezes com pontos rubiginosos. Flores estaminadas 1-4 por cimo, distantes entre si 0,5-1,5 cm compr., creme a verdeclaras, comumente pontuadas de vermelho; pedicelo 1-2 mm compr.; perigônio campanulado, 2-2,5 mm compr., pontuado de vermelho, tubo mais curto que os lobos; tépalas 1-1,5 mm compr., 0,6-0,8 mm larg., patentes, reflexas, elípticas, agudas a obtusas no ápice, 1-nervura; estames 6 , exsertos, livres, 


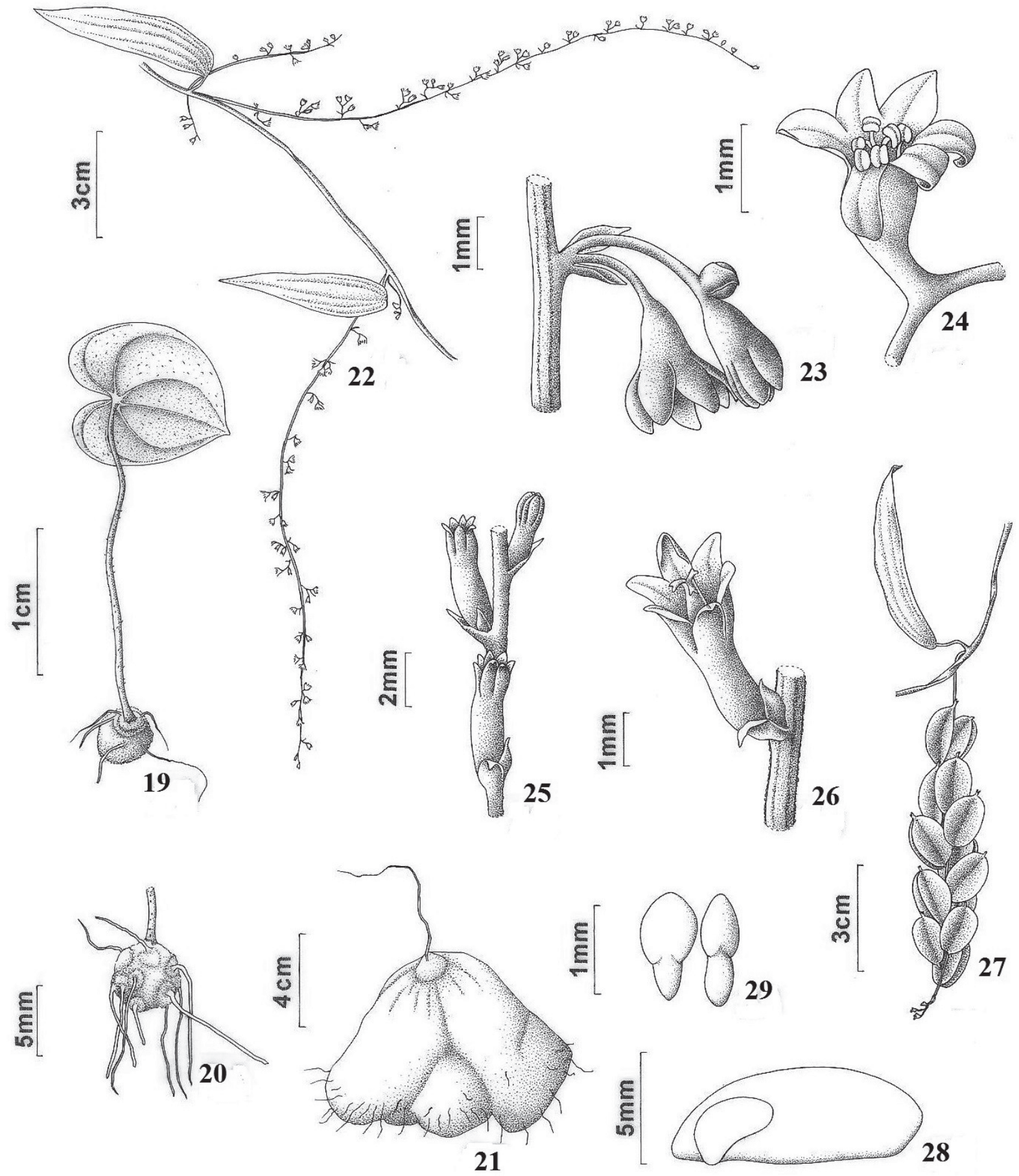

Figuras 19-29. Dioscorea sanpaulensis R. Knuth. 19-20. Plantinhas de 90 e 120 dias. 21. Tubérculo de planta adulta. 22. Ramo com inflorescências estaminadas. 23. Flores estaminadas cimosas. 24. Flor estaminada. 25. Fragmento de inflorescência pistilada. 26. Flor pistilada. 27. Infrutescência. 28. Semente. 29. Embriões (19-20. M. Kirizawa 3460, 21. M. Kirizawa 3468, 22. M. Kirizawa \& M. Sugiyama 1372, 23-24. L.R. Landrum 2767, 25-26. M. Kirizawa 1126, 27. M. Kirizawa \& C.C. Xifreda 3526. 28-29. M. Kirizawa 3460).

Figures 19-29. Dioscorea sanpaulensis R. Knuth. 19-20. Young plants of 90 and 120 days. 21. Tuber of an adult plant. 22. Branch with staminate inflorescences. 23. Cymose staminate flowers. 24. Staminate flower. 25. Pistillate inflorescence fragment. 26. Pistillate flower. 27. Infructescence. 28. Seed. 29. Embryos (19-20. M. Kirizawa 3460, 21. M. Kirizawa 3468, 22. M. Kirizawa \& M. Sugiyama 1372, 2324. L.R. Landrum 2767, 25-26. M. Kirizawa 1126, 27. M. Kirizawa \& C.C. Xifreda 3526, 28-29. M. Kirizawa 3460). 
fixos no base do perigônio, filetes $0,8-1 \mathrm{~mm}$ compr., ultrapassando um pouco o tubo, eretos, espessados e com pontos rubiginosos no ápice, anteras extrorsas, 0,3-0,4 mm compr., elípticas, encurvadas, creme; pistilódio pequeno, trígono. Inflorescência pistilada espiga, simples, 1 por axila, 3,5-11 cm compr., raque angulada, escabrosa, verde-avermelhada; pedúnculo 1,5-5 cm compr.; bractéolas 2, desiguais, ovadoacuminadas. Flores pistiladas sésseis, verde-limão, externamente vináceas; perigônio campanuliforme, 1,2-2 mm compr., partido ca. $1 / 2$ metade superior; tépalas 1,1-1,2 $\mathrm{mm}$ compr., 0,5-0,6 $\mathrm{mm}$ larg., ereto-patentes; estaminódios 6 , anteríferos, ca. 1/2 comprimento do estilete; ovário 1,5-2 $\mathrm{mm}$ compr., verde, cristas vináceas, estilete colunar piramidal, ca. $1 \mathrm{~mm}$ compr., 3-partido no ápice, cada ramo não lobado, verde. Cápsula 1,1-2 cm compr., 0,7-1,4 cm larg., elíptico-oblonga, ápice e base arredondados, pontuada de vermelho, rígida-membranácea; sementes 0,8-1,2 cm compr., 0,3-0,5 m larg., ala posterior elíptico-oblonga.

Material examinado: BRASIL. S̃̃o PAULO: Santo André, Campo Grande, fl. ô, XI-1913, A.C. Brade 7212 (SP, NY isoparatipo); Reserva Biológica do

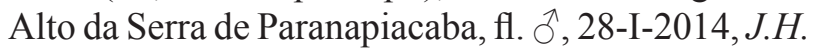
da Silva \& M. Kirizawa 1 (SP); fl. ㅇ, fr., 28-I-2014, J.H. da Silva \& M. Kirizawa 2 (SP); fl. \&, fr., 28-I-2014, J.H. da Silva \& M. Kirizawa 3 (SP); fl. ㅇ, fr., 28-I-2014, J.H. da Silva \& M. Kirizawa 9 (SP);

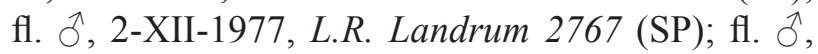
28-III-1983, M. Kirizawa 898 (SP); fl. đ̄, 14-XI-1983, M. Kirizawa 1109 (= MK898, SP); fl. Ō, 12-I-1985, M. Kirizawa 1373 (SP); fr., 14-IV-1989, M. Kirizawa 2136 (SP); cultivado no Instituto de Botânica, fl. ô, 26-XII-1991, M. Kirizawa 2841 (SP); cultivado no Instituto de Botânica, fl. ㅇ, 15-X-1985, M. Kirizawa 1507 (SP = MK1172); fl. Ō, 6-XI-1991, M. Kirizawa et al. 2553 (SP); fl. Ō, 20-XI-1984, M. Kirizawa \& T.P. Guerra 1341(SP); fl. ô, fl. ๆ, 29-XI-1983, M. Kirizawa \& E.A. Lopes 1114, 1118, 1119, 1121, 1122, $11251126,1127,1128$ (SP); trilha Washington Luís, área de campo, fr., 27-III-1984, M. Kirizawa \& M. Sugiyama 1172, 1173, 1174, 1185 (SP); fl. ô, fl. + , fr., 12-I-1985, M. Kirizawa \& M. Sugiyama 1371, 1372, 1374, 1375 (SP); área de Campo Grande, trilha 30, fl. $\widehat{o}$, fl. + , 12-XII-2003, M. Kirizawa et al. 3453, 3454, 3455 (SP).

Ocorre na Mata Atlântica e campos dos Estados de Minas Gerais (Serra do Gongo-Seco), São Paulo e Paraná (Kirizawa et al. 2010, Kaehler et al. 2014). Na
Reserva Biológica de Paranapiacaba, D. sanpaulensis cresce na região de morros ondulados de Campo Grande, onde se localiza a formação arbustiva baixa sobre solo argilo-arenoso e que às vezes é atingida por fogo. Um dos exemplares observados na Reserva apresentou vários bulbilhos na base dos pecíolos áfilos ou com limbo reduzido. Para Burkill (1960) um bulbilho é um ramo que compete com túberas para estocar alimento, sendo indiscutível sua potencialidade para propagação. No caso de D. sanpaulensis, ocorrente em solo mais pobre, talvez auxilie na sobrevivência da espécie em caso de necessidade. Para esclarecer melhor o papel dos bulbilhos seriam necessários estudos morfo-anatômico e fisiológico com enfoque ambiental. Coletada com flores estaminadas geralmente de novembro a dezembro, mais raro em março; flores pistiladas de outubro a dezembro, janeiro, às vezes em abril. Frutos verdes são visíveis de janeiro a março, os secos de março e abril, quando a parte aérea já está em processo de senescência.

Couto et al. (2013) incluíram Dioscorea sanpaulensis na categoria EN (em perigo) no Livro Vermelho da Flora do Brasil.

6. D. tauriglossum R. Knuth in H.G.A. Engler (ed.), Pflanzenr. IV,43 (87): 350. 1924.

Dióica, vigorosa, podendo atingir 5-6 m alt., glabra ou quase, tricomas não bulbosos; sistema subterrâneo discoide, levemente lobado. Caule sinistrorso, subcilíndrico, 2-4 mm larg., verde-vináceo, estrias verdes, entrenós basais longos, 7-18(-24) cm compr., providos de lâmina rudimentar ovado-linear, longamente acuminada ou áfilos, com genículo basal persistente, entrenós superiores (2-)7-15 cm compr. Folhas alternas; lâmina 9-25 cm compr., (1,5-)3-10 cm larg.; lanceolada, ovado a oblongolanceolada, às vezes ovado-elíptica, ápice abrupta a longamente acuminado, encurvado unilateralmente, base levemente constricta, aguda a arredonda, margem revoluta, 5-7 nervuras, 3 nervuras de contorno linearlanceolado proeminentes na face abaxial, as submarginais tênues, rígido-membranácea, verde-escura, glabra ou quase, com glândulas na base foliar; pecíolo 2-6 cm compr., 2-4 mm larg., face adaxial sulcada, genículo basal vináceo, robusto, pelos tectores simples, alvos, em folha jovem, glabro na adulta. Inflorescência estaminada racemosa com cimos, 1-2 por axila, simples, às vezes ramificada próximo da base, 6,0-45(-58) cm compr., pêndula; raque levemente alada, com glândulas rubiginosas; pedúnculo $0,5-1 \mathrm{~cm}$ 
compr.; blactéolas 2, ovado-acuminadas, oblongolanceoladas, longamente acuminadas, glabras. Flores estaminadas em cimo escorpióide, 0,5-1,2 cm compr., 2-7 flores, creme a verde-claras, carnosas, tubo verde-escuro; pedicelo 0,5-1,2 mm compr., estriado, com glândulas rubiginosas; perigônio campanulado, 1,5-2,5 $\mathrm{mm}$ compr., 3/4 representado por tubo com numerosas glândulas rubiginosas; tépalas 0,8-1 mm compr., 0,4-0,5 mm larg., eretopatentes, estreitamente elípticas a oblongas, ápice agudo, margem levemente revolutas, 1-nervura inconspícua, verde-escuras, glabras; estames 6, inclusos, livres, fixos na base do tubo do perigônio, filetes $0,5-0,7 \mathrm{~mm}$ compr., densamente pontuados, alargados na base, eretos, encurvados no terço apical, anteras extrorsas, ca. 0,5 mm compr., ovais-elípticas; pistilódio reduzido, tricúspide. Inflorescência pistilada espiga, simples, 1-2 por axila, às vezes ramificada próximo da base, $14-35 \mathrm{~cm}$ compr., raque anguladoestriada, verde-vinácea, glabra, 10 a 30 flores, distantes $0,5-2,5 \mathrm{~cm}$ entre si; pedúnculo $2-6,5 \mathrm{~cm}$ compr., glabro, verde-vináceo, estriado; bractéolas 2 , ovadas, longamente acuminadas. Flores pistiladas sésseis, verde-avermelhadas; perigônio campanulado, ca. $1 \mathrm{~mm}$ compr., até $1 / 2$ unidos formando tubo; tépalas ca. $1 \mathrm{~mm}$ compr., ca. 0,4 mm larg., elípticas, ápice agudo, ereto-côncavas 1-nervura; estaminódios anteríferos 6, filetes curtos, anteras creme; ovário 2,5-5 mm compr., verde-claro, carnoso, salpicado de rafídeos e pelos glandulares; estilete colunar piramidal, $1 / 2$ menor que o perigônio., 3-partido no ápice, cada ramo levemente 2-lobado. Cápsula 2,5-3,5 cm compr., 1,4-1,6 cm larg., elíptico-oblonga, verde escura ao longo do eixo mediano, ápice agudo, base arredondada a quase retusa, bordo espessado, glabra; sementes 2-2,7 cm compr., castanhas, ala posterior oblonga a lanceolada, embrião 2-3 mm compr.

Material examinado: BRASIL. São Paulo. Santo André, Reserva Biológica do Alto da Serra de Paranapiacaba, fl. Ĵ, 3-IV-1923, F.C. Hoehne s.n. (SP 8262, isotipo); tubérculo coletado na Reserva Biológica de Paranapiacaba, cultivado em São Paulo, no Instituto de Botânica, fl. ô, 7-III-1986, M. Kirizawa 1583 (= M. Kirizawa, 1386, 1421) (SP); idem, fl. đ̃, 29-IX-1986, M. Kirizawa 1750 (SP); idem, fl. ô, 12-XII-1986, $M$. Kirizawa, 1769 (SP); fl. §ิ, 22-III-1985, M. Kirizawa 1421 (SP); Reserva Biológica do Alto da Serra de Paranapiacaba, fl. Õ, 24-II-1987, M. Kirizawa 1826 (SP); fl. §̄, 1-VI-1990, M. Kirizawa 2270 (SP); fl. đ̄, 26-II-1985, M. Kirizawa \& T.P. Guerra 1386 (SP); fl. ô, 3-V-2002, M. Kirizawa \& R.P. Romanini 3451 (SP).
Material adicional examinado: BRASIL. São PAUlo. Santo André, perto da vila de Paranapiacaba, fr., 15-X-1996, M. Kirizawa \& E.A. Lopes 3306 (SP); fl. +, fr. imaturo, 31-I-1996, M. Sugiyama et al. 1404 (SP).

Ocorre no Estado de São Paulo, Serra do Mar, na mata pluvial de encosta. É planta vigorosa, de sub-bosque e de ambiente úmido rico em serapilheira; provido de tubérculo desenvolvido, com 11-23(-29) $\mathrm{cm}$ de diâmetro e $6-13 \mathrm{~cm}$ de espessura, pesando cerca de $300 \mathrm{~g}$. (peso a fresco); nos exemplares mais desenvolvidos pode atingir aproximadamente $1,5 \mathrm{~kg}$. (peso a fresco). Localizado entre 10 a $15 \mathrm{~cm}$ de profundidade, o tubérculo emite raízes fibrosas e caules aéreos que atingem mais de $3 \mathrm{~m}$ de altura. Observada com flores estaminadas em fevereiro e agosto, com floração intensa de outubro a dezembro, folhas senescentes em abril; flores pistiladas e frutos em outubro, janeiro e fevereiro.

Knuth (1924) descreveu a D. tauriglossum com base no material-tipo masculino (B, SP!) coletado por Hoehne no Alto da Serra em 1923. A espécie apresenta semelhança com D. bulbotricha Hand.Mazz. e D. delicata R. Knuth, diferindo por estas apresentarem tricomas tectores setuliformes de base bulbosa no caule e folha, lâmina ovado-cordiforme, com sinus basal ou ovado-lanceolada com base cordiforme; perigônio globoso-tubuliforme a globosocampanulado, quase urceolado. As três espécies de Dioscorea anteriormente citadas pertencem a Seção Dematostemon.

Ilustrações em Kirizawa \& Romanini (2003, fig. 36-48)

7. Dioscorea torticaulis R. Kunth, in H.G.A. Engler (ed.) Pflanzenr. IV, 43 (87):351-352. 1924.

Figuras 30-40

Dióica, ca. 1,6 m alt., subglabra; sistema subterrâneo tuberiforme, ovalado ou lobado, pequeno, 1-2 cm larg., quase achatado $0,5-1,3 \mathrm{~cm}$ espessura. Caule sinistrorso, delicado, estriado, 0,5-1 mm larg., ala escabrosa, entrenós 6,5-20 cm compr., longos na região basal; acúleos ausentes. Folhas alternas; lâmina 3-8 cm compr., 1,5-5,5 cm larg., ovada a ovado-elíptica ou ovado-lanceoladas, ápice abrupta a longamente acuminado, base obtriangular a côncava, sinus basal estreito, margem escabrosa, 5-7 nervuras, as laterais 1-ramificada, membranácea, verde-escura na face adaxial, mais clara na abaxial, com glândulas esféricas na base e tricomas glandulares 


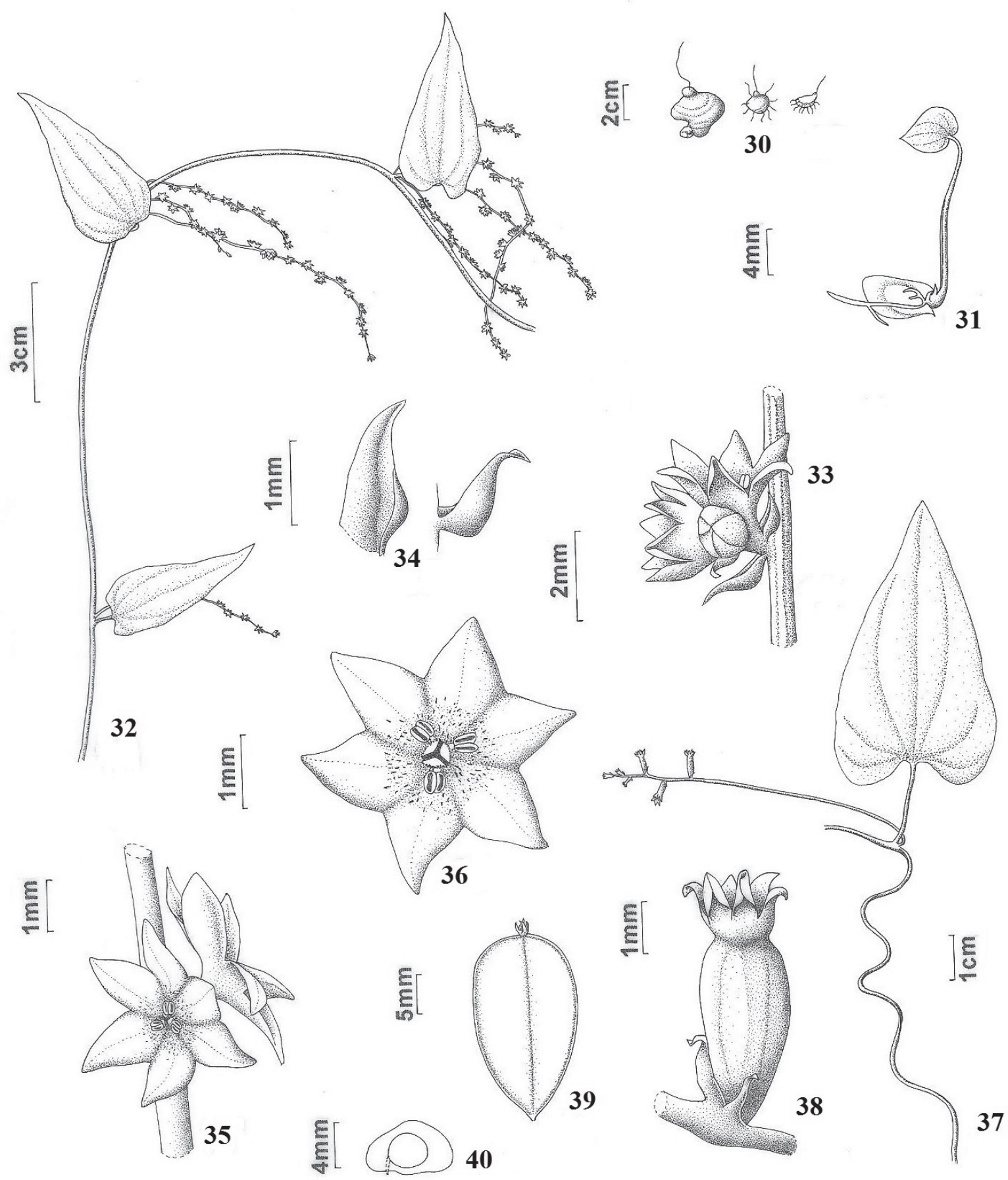

Figuras 30-40. Dioscorea torticaulis R. Knuth. 30. Tubérculos de diferentes tamanhos. 31. Plântula. 32. Ramo de inflorescência estaminada. 33. Cimo de flores estaminadas. 34. Bracteólas. 35-36: Flores estaminadas. 37. Ramo de inflorescência pistilada. 38. Flor pistilada. 39. Fruto. 40. Semente (30. M. Kirizawa 1151, 31. M. Kirizawa et al. 775, 32. L.B. Smith 1950, 33-36. M. Kirizawa 3554, 37. M. Kirizawa et al. 774, 38. M. Kirizawa 1192, 39. M. Kirizawa 1154, 40. M. Kirizawa 1153).

Figures 30-40. Dioscorea torticaulis R. Knuth. 30. Different sizes of tubers. 31. Seedling. 32. Branch with staminate inflorescence. 33. Cyme of staminate flowers. 34. Bracteoles. 35-36. Staminate flowers. 37. Branch with pistillate inflorescence. 38 . Pistillate flower. 39. Fruit. 40. Seed (30. M. Kirizawa 1151, 31. M. Kirizawa et al. 775, 32. L.B. Smith 1950, 33-36. M. Kirizawa 3554, 37. M. Kirizawa et al. 774, 38. M. Kirizawa 1192, 39. M. Kirizawa 1154. 40. M. Kirizawa 1153). 
escuros; pecíolo 1-2,5(-3,5) cm compr., estriado e escabroso. Inflorescência estaminada racemo com glomérulos, 1-3 por axila, simples, às vezes ramificada próximo da base, 3-13 cm compr., raque estriadoalada, escabrosa; pedúnculo 0,3-0,5(-1) cm compr.; bractéolas 2, cimbiformes a ovadas, acuminadas. Flores estaminadas cimosas, glomérulos 1-6 flora, verdes a creme; margens lilases; pedicelo menor que $1 \mathrm{~mm}$ compr. a quase séssil; perigônio radiado, 3-3,6 mm diâm., tubo ca. $1 \mathrm{~mm}$ compr., ca. $1 / 4$ mais curto que os lobos, às vezes com pontos e riscos vináceos; tépalas 1-1,2 mm compr., 0,7-0,8 mm larg., patentíssimas, triquetras e revolutas, ápice agudo a obtuso, 1-nervura; estames 3, livres, fixos na base do tubo, filetes curtíssimos, eretos, encurvados no ápice, anteras ca. $0,2 \mathrm{~mm}$ compr., introrsas, tecas viradas para cima, elípticas; estaminódios ausentes; pistilódio ausente. Inflorescência pistilada espiga, simples, 1 por axila, 4-10 cm compr., flores até 7, raque estriado, escabroso; pedúnculo 2-6 cm compr.; bractéolas 2, ovado-elípticas, margem escabrosa, verde-claras. Flores pistiladas verdes a amarelo-claras; perigônio $1,2-1,5 \mathrm{~mm}$ compr., tubo ca. $1 / 4$ mais curto que os lobos; tépalas semelhantes às das flores estaminadas, ca. $1 \mathrm{~mm}$ compr., ca. 0,7 mm larg., ereto-recurvadas, patentes, 1-nervura; estaminódios anteríferos 3 , perto da coluna do estilete; ovário 1,5-2,5(-3) mm compr., às vezes pontuado de vermelho; estilete colunar, mais curto que o tubo do perigônio, 3-partido no ápice, cada ramo simples, divergente, recurvado. Cápsula 1-2,2 cm compr., 0,7-1,6 cm larg., comumente obovoide, às vezes levemente globoso a elíptico, ápice obtuso a quase retuso, base aguda, sementes 6-9 mm compr., 3,5-5 mm larg., plano-convexa, ala semi-circular.

Material examinado: BRASIL. São PAULO: Santo André, Reserva Biológica do Alto da Serra de Paranapiacaba, fl. Oे, 25-I-1922, A. Gehrt s.n. (SP7878); Estação Biológica, Alto da Serra, fl. đ̃, fr., 4-III-1918, F.C. Hoehne s.n. (SP1597, NY); fl. ㅇ , 2-III-1932, W. Hoehne s.n. (SP246871 = SPF16615); fl. §ै, fl. ㅇ, 26II-1985, M. Kirizawa \& T.P. Guerra 1379, 1381, 1385 (SP); fl. O, fr., 15-III-1995, M. Kirizawa \& E.A. Lopes 2954 (SP); fl. q, fr., 5-V-1982, M. Kirizawa et al. 774, 775, 776 (SP); fl. ô, fl. ㅇ, fr., pl. jovem, 28-II-1984, M. Kirizawa et al. 1150, 1151, 1152, 1153, 1154, 1155, 1156, 1171 (SP); fl. ô, fr., 17-IV-1984, M. Kirizawa et al. 1191, 1192, 1193, 1194 (SP); fl. Oे, 16-I-2007, M. Kirizawa 3554 (SP); fl. Ō, 5-III-1964, J. Mattos 11464 (SP); fl. $\widehat{~ O, ~ 28-I-1983, ~ M . ~ S u g i y a m a ~ \& ~ A . ~ C u s t o d i o ~}$

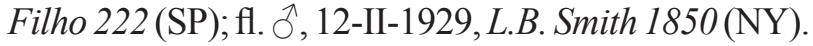

Material adicional examinado: BRASIL. São PAULo: Santo André, Alto da Serra, Serra do Mar, fl. ô, 2-XI-1913, A.C. Brade 5890 (SP6983 isotipo).

Espécie encontrada no Estado de São Paulo, em área restrita da Serra do Mar, a 700-800 m.s.m. É planta delicada de sub-bosque, provida de tubérculo pequeno, com raízes fibrosas curtas e localizado a menos de $10 \mathrm{~cm}$ de profundidade, em ambiente úmido e rico em serapilheira. Na Reserva Biológica de Paranapiacaba, os exemplares masculino e feminino são encontrados próximos um do outro, na beira de uma trilha perto da Casa do Naturalista; até o momento, não têm sido encontrados em outras áreas. Observada com flores estaminadas de janeiro a abril e flores pistiladas de fevereiro a maio, raramente em dezembro. Frutificam de fevereiro a maio, apresentando frutos secos, totalmente deiscentes, em dezembro.

Knuth (1924) descreveu $D$. torticaulis, com base na coleta de A.C. Brade 5890, exemplar masculino, no Alto da Serra, Serra do Mar, em 1913 (isotipo!), incluindo-a na Seção Hemidematostemon. Na mesma obra, dentro da Seção Triapodandra Uline, Knuth apresenta a descrição de D. kunthiana Uline ex R. Knuth utilizando duas coletas de exemplar masculino, uma feita por Schwacke 10381 em Minas Gerais, Serra do Ouro Preto, e a outra por F.C. Hoehne (SP1597) em 1918 na Estação Biológica, atual Reserva Biológica de Paranapiacaba, adjacente à Estação Ferroviária Alto da Serra, São Paulo; portanto, em duas regiões geograficamente distintas em termos de fisionomia e clima: campo rupestre e mata atlântica. A análise das descrições e de materiais-tipo de $D$. torticaulis e D. kunthiana citados por Knuth $(1917,1924)$ bem como de diversos exemplares masculinos coletados na Reserva Biológica de Paranapiacaba revelam que as duas espécies diferem entre si, principalmente por caracteres observados na lâmina foliar e flores estaminadas. Dioscorea torticaulis, em contraste com D. kumnthiana, apresenta lâmina foliar sem glândulas rubiginosoas, venação laxa, 5-7 nervuras, consistência geralmente membranácea, perianto verde ou creme, radiado, não purpúreo ou rotáceo, tépalas triquetras e revolutas. Esses caracteres foram igualmente apresentados pelo material de Hoehne (SP1597) incluído em D. kunthiana por Knuth (1924) e excluído pelos autores deste trabalho. Estes descrevem pela primeira vez o exemplar feminino, frutos e sementes, complementando assim a caracterização de $D$. torticaulis R. Knuth.

Os autores deste trabalho consideram Dioscorea torticaulis como espécie rara, de distribuição restrita à 
Reserva Biológica de Paranapiacaba. Não há registro desta espécie no Parque Natural Municipal Nascentes de Paranapiacaba.

8. Dioscorea trilinguis Griseb. in Kjoebsk. Vidensk. Meddel.Naturhist.Foroen.Krabenhavn 9-15:163. 1875; R. Knuth in H.G.A. Engler (ed.) Pflanzenr. IV, 43 (87): 251. 1924.

Figuras 41-47

Sinônimo: Dioscorea trilinguis Grise. var. edwallii Uline ex R. Knuth. Notizbl. bot. Gart. u. Mus. Berlin VII: 218. 1917; R. Knuth, in H.G.A. Engler (ed.). Pflanzenr. IV, 43 (87): 251. 1924. (Typus: S. Paulo, Caraguatatuba, leg. Edwall 1763, SP!).

Dióica, ca. 1,60 m alt., glabra a glabrescente; sistema subterrâneo rizomatoso, fragmento horizontal 7,5-13 cm compr., 1-2,8 cm larg. Caule aéreo sinistrorso, cilíndrico, estriado, 1-2 mm larg., entrenós 4-13 cm compr., ramos desenvolvidos com superfície tuberculada e esfoliante; acúleos ausentes. Folhas alternas, variáveis na forma e dimensões, 3-7 nervuras; lâmina profundamente 3-lobada nos nós basais, lobo mediano lanceolado, 3-nervado, lobos laterais divergentes, obliquamente ascendentes, de um extremo a outro 3-12 cm larg., 1-2 nervuras, nervura externa ramificada próximo da base, quando inteira, 3,5-9,5(-15) cm compr., 1-8 cm long., ovada, elíptica a lanceolada, sagitiforme, ápice agudo a acuminado, base cordada a sagitada a quase retusa, nervura marginal conspícua e castanho-avermelhada, rígido-membranácea, verde a verde-avermelhada, glabra a escassamente pubescente; pecíolo 1,2-3,5 cm compr. Inflorescência estaminada racemo, 1 por axila, simples, 2-5 cm compr., quando panícula 9,5-30 cm compr., ramos laterais numerosos, 0,8-7 cm compr., raque angulada multiflora; pedúnculo $0,5-2 \mathrm{~cm}$ compr.; bractéolas 2, desiguais, ovado-triangulares, longamente acuminadas, 1-nervura, pontuadas, exceto na margem. Flores estaminadas pediceladas, solitárias, vináceas, carnosas; pedicelo ca. $1 \mathrm{~mm}$; perigônio hipocrateriforme, 3,5-3,8 mm compr., tubo mais longo que os lobos, 1,5-2,2 mm; tépalas 1,5-1,8 mm compr., 0,8-1,2 mm larg., elípticas, oblongas a ovadooblongas, patentíssimas, ápice obtuso, 1-nervura inconspícua, numerosos pontos rubiginosos, exceto no bordo; estames férteis 3, livres, exsertos, fixos na base do tubo do perigônio, filetes ca.0,5 mm compr., eretos, verdes, anteras ca. $1 / 4$ do compr. do filete, introrsas, oblongas, amarelas; estaminódios não anteríferos 3, filiformes, mais curtos que os filetes de estames férteis; pistilódio pequeno, cônico. Inflorescência pistilada espiga, 1 por axila, simples, 13-26,5 cm compr., rígida e ereta; pedúnculo 3,0-3,5 cm compr.; raque angulada, verde, glabrescente; bractéolas 2, a externa maior que a interna, ovado-acuminadas, 1-nervura. Flores pistiladas sésseis, vináceas, carnosas; perigônio estipitado, hipocrateriforme, tubo 2-3 mm compr., verde; tépalas 1,8-2 $\mathrm{mm}$ compr., 0,8-1,5 mm larg., ovado-elípticas, patentíssimas, ápice obtuso, 1-nervura inconspícua; estaminódios anteríferos 3, fixos na base do tubo, anteras elíptico-oblongas, introrsas, amarelas; ovário 3-5 mm compr., trígono, avermelhado, glabrescente, estilete colunar piramidal, mais curto que o tubo do perigônio, 3-partido no ápice, cada ramo 2-fido, falconiforme, achatado, esverdeado. Cápsula imatura 5-6 mm compr., 0,9-1,0 mm larg., valvas mais largas no ápice, estreitando-se para a base, avermelhada, numerosos pontos rubiginosos. Segundo Knuth (1924), cápsula madura é orbicular; sementes elípticas, aladas nas duas extremidades.

Material examinado: BRASIL. São PaUlo: Santo André, Reserva Biológica do Alto da Serra de Paranapiacaba, cultivado em São Paulo, fl. $\widehat{\jmath}$, 6-II-1985, M. Kirizawa 1495 (SP); Reserva Biológica do Alto da Serra de Paranapiacaba, fl. 9 , fr. imaturo, 3-V-2002, M. Kirizawa \& R.P. Romanini 3452 (SP).

Material adicional examinado: BRASIL. RIO DE JANEIRO: Rio de Janeiro, cume de Corcovado, fl. $\widehat{\jmath}$, 9-V-1873, II-1874, A. Glaziou 6738 (P, K,B - tipos de D. trilinguis); fl. Õ, 21-IV-1864, A. Glaziou 1118 (P, D. trilinguis var. edwallii Uline); São PaUlo: Caraguatatuba, 13-IV-1892, fl. §̊, G. Edwall s.n., CGG 1763 (SP9092, isotipo de D. trilinguis var. edwallii Uline); fl. Ō, 30-IV.1966, A.S. Grotta et al. s.n. (SP246866, SPF46422); São Paulo, fl. Ō, 3-IV-1946, A. Gehrt s.n. (SP53704); fl. ㅇ, 3-IV-1946, A. Gehrt s.n. (SP53705).

Ocorre no Rio de Janeiro e São Paulo, nesse Estado na Serra do Mar e na mata mesófila do Planalto Paulistano. Na Reserva Biológica de Paranapiacaba, D. trilinguis é rara, tendo sido encontrada somente na parte baixa de morros ondulados cobertos por mata ombrófila densa secundária, baixa, sobre solo argiloso-arenoso. À semelhança do material adicional examinado, D. trilinguis da Reserva Biológica de Paranapiacaba apresenta igualmente diversidade no formato da lâmina foliar, variando de inteira a leve ou profundamente trilobada. Coletada com flores estaminadas em julho e as femininas em maio. 


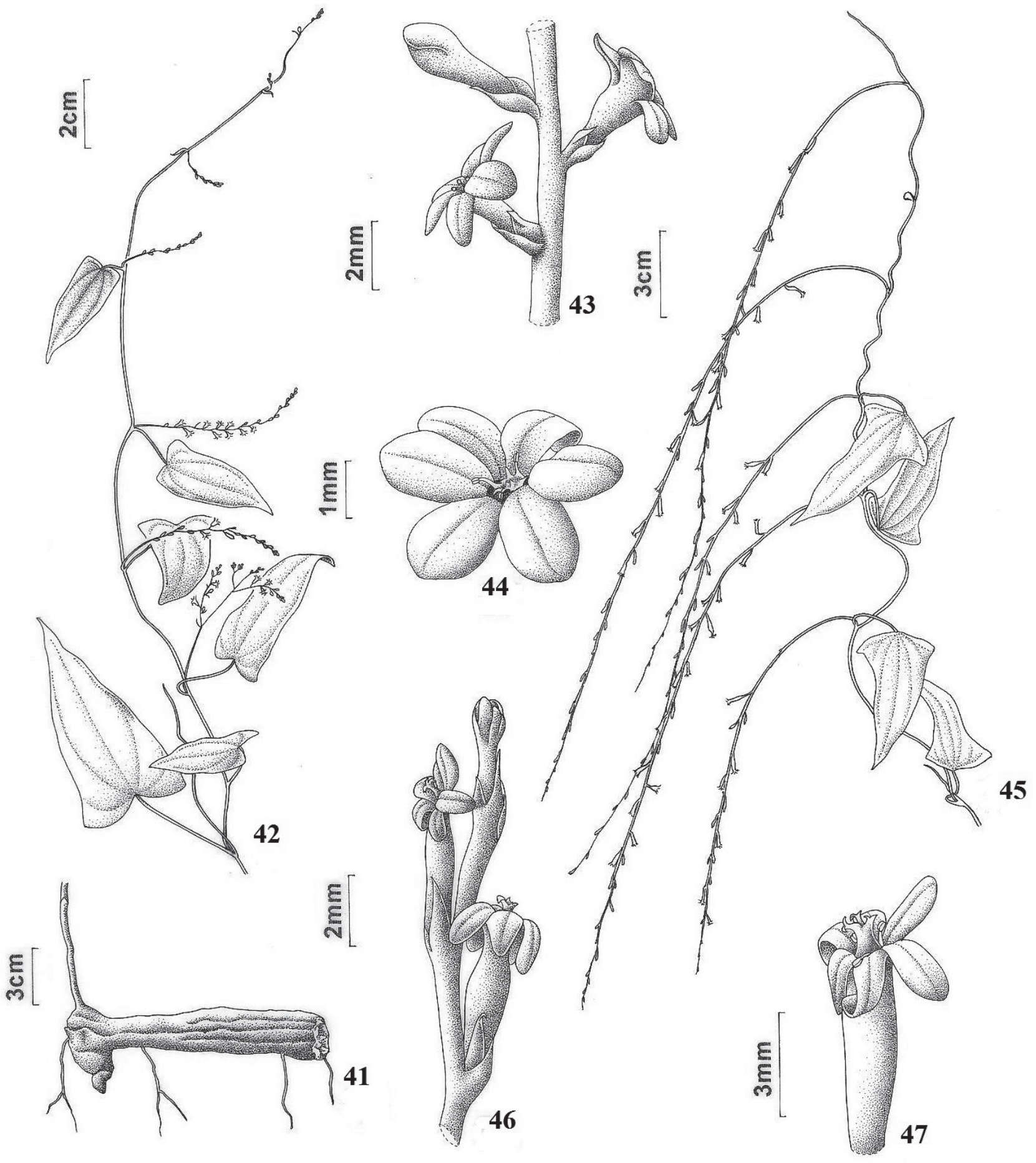

Figuras 41-47. Dioscorea trilinguis Griseb. 41. Fragmento do rizoma. 42. Ramo com inflorescências estaminadas. 43. Detalhe da inflorescência estaminada. 44. Flor estaminada. 45. Inflorescências pistiladas. 46. Detalhe da inflorescência pistilada. 47. Flor pistilada (41-44. M. Kirizawa 1495, 45-47. M. Kirizawa \& R.P. Romanini 3452).

Figures 41-47. Dioscorea trilinguis Griseb. 41. Rhizome fragment. 42. Branch with staminate inflorescences. 43. Detail of a staminate inflorescence. 44. Staminate flower. 45. Pistillate inflorescences. 46. Detail of a pistillate inflorescence. 47. Pistillate flower (41-44. M. Kirizawa 1495, 45-47. M. Kirizawa \& R.P. Romanini 3452). 
Couto et al. (2013) incluíram Dioscorea trilinguis na categoria EN (em perigo) no Livro Vermelho da Flora do Brasil.

\section{Conclusões}

As Dioscoreaceae da Reserva Biológica do Alto da Serra de Paranapiacaba são trepadeiras providas de sistema subterrâneo tuberiforme ou rizomatoso, superficial, folhas inteiras, trilobadas apenas em $D$. trilinguis. Incluídas no subgênero Helmia (Kunth) Benth., Seção Dematostemon Griseb., D. bulbotricha, $D$. sanpaulensis e D. tauriglossum apresentam flores estaminadas racemosas dispostas em cimo, perigônio globoso-campanulado a campanulado, seis estames, filetes longos, eretos, e ala seminal posterior; no entanto, diferem entre si, por outros caracteres, como: forma da lâmina foliar, do tricoma, dimensões do fruto e área de ocorrência. De todas as Dioscorea citadas na Reserva de Paranapiacaba, a D. monadelpha da Seção Monadelpha é a única trepadeira monóica, facilmente reconhecida no campo pelas flores estaminadas pediceladas, isoladas, androceu colunar, purpúreo. As espécies restantes pertencem a três seções do subgênero Dioscorea, com ala seminal circular, flores estaminadas em gromérulos, filetes curtos ou subsésseis, caracteres observados em Dioscorea marginata e D. torticaulis pertencentes respectivamente às Seções Apodostemon Uline e Triapodandra Uline. No entanto, elas diferem quanto ao perianto e número de estames, a $D$. marginata apresentando perianto rotáceo, segmentos ovados, seis estames, e a $D$. torticaulis, radiado, segmentos triquetros, bordo revoluto, três estames. A $D$. trilinguis da Seção Periandrum Uline diverge das espécies anteriormente analisadas, por apresentar sistema subterrâneo rizomatoso, flores estaminadas com três estames férteis e três estéreis.

Como foi explicitado nas observações taxonômicas, vale registrar que os autores desse trabalho divergem das sinonimizações de $D$. delicata e D. tauriglossum em D. ovata Vell.; de D. kunthiana em D. filiformis Griseb.; D. marginata em D. spicata (Vell.) Pedralli e de D. sanpaulensis em D. campestris, efetuadas por Pedralli em 1997 e 2004.

São necessários futuros estudos visando a conservação e propagação vegetativa e/ou reprodutiva de Dioscorea sanpaulensis, D. torticaulis e $D$. trilinguis, espécies ameaçadas de extinção.

\section{Agradecimentos}

Aos curadores dos herbários, especialmente de ESA, IAC, SP, SPF, UEC, ao Klei Sousa e Maria
Cecília Tomasi pela execução de algumas figuras e arte final; e a Pesquisadora Científica Elisabete Aparecida Lopes pela revisão crítica.

\section{Literatura citada}

Andreata, R.H.P. 1979. Smilax spicata Vell. (Smilacaceae). Considerações taxonômicas. Rodriguesia 50: 105-115.

Andreata, R.H.P. 1980. Smilax Linnaeus (Smilacaceae). Ensaio para uma revisão taxonômica das espécies brasileiras. Arquivos do Jardim Botânico do Rio de Janeiro, Rio de Janeiro 24: 179-301.

Andreata, R.H.P. 1997. Revisão das espécies brasileiras do gênero Smilax Linnaeus (Smilacaceae). Pesquisas, Botânica 47: 75-79.

Barroso, G.M., Sucre, D., Guimarães, E.F., Carvalho, L.F., Valente, M.C., Silva, J.D., Silva, J.B., Rosenthal, F.R.T., Barbosa, C.M. \& Roseira, A.N. 1974. Flora da Guanabara. Família Dioscoreaceae. Sellowia 25: 9-256

Burkill, K. 1960. The organography and the evolution of Dioscoreaceae, the family of the yans. Botanical Journal of Linnean Society 56: 319-412.

Caddick, L.R., Furness, C.A., Stobart, K.L. \& Rudall, P.J. 1998. Microsporogenesis and pollen morphology in Dioscoreales and allied taxa. Grana 37: 321-336.

Caddick, L.R., Rudall, P.J., Wilkin, P., Hedderson, T.A.J., Rudall, P.J. \& Wilkin, P. 2000. Floral morphology and development in Dioscoreales. Feddes Repertorium 111: 189-230.

Caddick, L.R., Rudall, P.J., Wilkin, P., Hedderson, T.A.J. \& Chase, M.W. 2002. Phylogenetics of Dioscoreales based on combined analyses of morphological and molecular data. Botanical Journal of Linnean Society 138: 123-144.

Caddick, L.R., Wilkin, P., Rudall, P.J., Hedderson, T.A.J. \& Chase, M.W. 2002a. Yams reclassifield: a recircumscription of Dioscoreaceae and Dioscoreales. Taxon 51: 103-114.

Chase, M.W., Soltis, D.E., Soltis, P.S., Rudall. P.J., Fay, M.F., Hahn, W.H., Sullivan, S., Joseph, J., Molvray, M., Kores, P.J., Givnish, T.J., Sytsma, K.J. \& Pires, J.C. 2000. Highner-level systematics of the Monocotyledons an assessment of current knowledge and a new classification. In: K.L. Wilson \& D.A. Morrison (eds.). Monocots: Systematic and evolution. Vitoria, CSIRO publishing, pp. 3-16.

Chu, E.P. 1989. Composição bioquímica de órgãos subterrâneos de reserva de espécies nativas de Dioscorea e análise do desenvolvimento de Dioscorea delicata R. Knuth. Dissertação de Mestrado, Instituto de Botânica, São Paulo.

Chu, E.P. \& Figueiredo-Ribeiro, R.C.L. 1991. Native and exotic species of Dioscorea used as food in Brazil. Economic Botany 45: 467-479.

Couto, R.S. 2010. Dioscoreaceae (R. Br.) Lindley do Estado do Rio de Janeiro, Brasil. Dissertação de Mestrado, Museu Nacional da Universidade Federal do Rio de Janeiro, Rio de Janeiro. 
Couto, R.S., Kirizawa, M., Santos Filho, L.A.F., Borges, R.A.X., Barros, F.S.M. \& Maurenza, D. 2013. Dioscoreaceae. In: G. Martinelli \& M.A. Moraes (eds.). Livro Vermelho da Flora do Brasil. Rio de Janeiro, Andre Jacobsson, Instituto de Pesquisas Jardim Botânico do Rio de Janeiro, pp. 481-484.

Dahlgren, R.M.T., Clifford, H.T. \& Yeo, P.F. 1985. The families of the monocotyledons. Structure, evolution and taxonomy. Berlin, Springer-Verlog, pp.107-128.

Govaerts, R., Wilkin, P. \& Saunders, R.M.K. 2007. World Checklist of Dioscoreales yams and their allies. Kew Publishing, Royal Botanic Gardens, Kew.

Grisebach, H.A. 1842. Dioscoreaceae. In: C.F.P. Martius, \& A.G. Eichler (eds.). Flora brasiliensis. Lipsiae, Fried Fleischer 3: 26-48.

Handel-Mazzetti, H.F. 1908. Dioscoreaceae. Denkschr. Kaiserl. Akad. WISS., Wien. Math.-Naturwiss. Kl. 79: 221-223.

Instituto Ekos. 2006. Instituto Ekos Brasil. Parâmetros da vegetação do Parque Natural Municipal Nascentes de Paranapiacaba, Santo André, SP.

Kaehler, M., Evangelista, P.H.L., Ribas, O.S., Vieira, A.O.S. \& Hatschbach, G.G. 2014. Plantas Vasculares do Paraná. Curitiba, Universidade Federal do Paraná, pp. 106-107.

Kinupp, V.F. \& Lorenzi, H. 2014. Plantas alimentícias não convencionais (PANC) no Brasil: guia de identificação, aspectos nutricionais e receitas ilustradas. Nova Odessa, Instituto Plantarum de Estudos da Flora Ltda, pp. 378-385.

Kirizawa, M. \& Romanini, R.P. 2003. Flora Fanerogâmica da Ilha do Cardoso (São Paulo, Brasil). Dioscoreaceae. Hoehnea 10: 11-35.

Kirizawa, M. \& Xifreda, C.C. 2009. Dioscoreaceae. In: J.R. Stehmann, R.F. Forzza, A. Salino, M. Sobral, D.P. Costa \& L.H.Y. Kamino (eds.). Plantas da Floresta Atlântica. Rio de Janeiro, Jardim Botânico do Rio de Janeiro. pp. 238-239.

Kirizawa, M. \& Xifreda, C.C. 2011. Dioscoreaceae. In: M.G.L. Wanderley, G.J. Shepherd, S.E. Martins, T.E.M.D. Estrada, R.P. Romanini, I. Koch, J.R. Pirani, T.S. Melhem, A.M. Giulietti-Harley, L.S. Kinoshita, M.A.G. Magenta, H.M.L. Wagner, F. Barros, L.G. Lohmann, M.C.E. Amara, I. Cordeiro, S. Aragaki, R.S. Bianchini \& G.L. Esteves (coord.). Checklist das Spermatophyta do Estado de São Paulo, Brasil. Biota Neotropica 11: 255-256.

Kirizawa, M., Sugiyama, M., Lopes, E.A. \& Custodio Filho, A. 2009. Parte IV. Flora. Capítulo 17. Fanerógamas: plantas com flores. In: M.I.M.S. Lopes, M. Kirizawa \& M.M.R.F. Melo (orgs.). Patrimônio da Reserva Biológica do Alto da Serra de Paranapiacaba. A antiga Estação Biológica do Alto da Serra. São Paulo, Instituto de Botânica, pp. 291-350.

Kirizawa, M., Xifreda, C.C., Couto, R.S. \& Araujo, D. 2010. Angiospermas: Dioscoreaceae. In: R.C. Forzza \& P. Leitman (coords.). Catálogo de plantas e fungos do Brasil. Rio de Janeiro, Andrea Jacobsson Estúdio \& Instituto de Pesquisas Jardim Botânico do Rio de Janeiro, v. 2, pp. 926-930.
Knuth, R. 1917. Dioscoreceae americanae novae. In: Notizblatt des König Botanischen Gartens und Museums zu Berlin-Dahlem n. 65, 7: 185-222.

Knuth, R. 1924. Dioscoreaceae. In: H.G.A. Engler (ed.). Pflanzenreich IV,43 87:1-387. Leipzig, Wilhelm Englelmann.

Ladeira, A., Chu, E.P., Mayworm, M.A.S. \& FigueiredoRibeiro, R.C.L. 1992. Seeds of Dioscorea delicata and D. olfersiana: germination and reserve compounds. Hoehnea 19: 135-142.

Pedralli, G. 1997. Revisão taxonômica das espécies de Dioscoreaceae (R.Br.) Lindley da cadeia do Espinhaço, Minas Gerais e Bahia. Tese de Doutorado, Universidade de São Paulo, São Paulo.

Pedralli, G. 2002. Levantamento florístico das Dioscoreaceae (R. Br.) Lindley da Cadeia do Espinhaço, Minas Gerais e Bahia, Brasil. Boletim de Botânica da Universidade de São Paulo 20: 63-119.

Pedralli, G. 2004. Dioscoreáceas. In: R. Reitz \& A. Reis (eds.). Flora Ilustrada Catarinense. Itajaí, Herbário Barbosa Rodrigues, pp. 1-83.

Prefeitura do Município de Santo André. 2008. Atlas do Parque Natural Municipal Nascentes de Paranapiacaba: revelando o nosso Parque. 2 ed. Annablume, São Paulo, SP.

Rudall, P.J., Cribb, P.J., Cutler, D.F. \& Humphries, C.J. 1995. Monocotyledons: systematics and evolution. Kent, Whitstable Litho Printers, v. 1, pp. 1-352.

Secretaria do Meio Ambiente. 1990. A Serra do Mar: degradação e recuperação. Série de Documentos, Instituto de Botânica, São Paulo, pp. 1-56.

Sugiyama, M., Santos, R.P., Aguiar, L.S.J., Kirizawa, M. \& Catharino, E.L.M. 2009. Parte III. Vegetação e Ecologia. Capítulo 7. Caracterização e mapeamento da vegetação. In: M.I.M.S. Lopes, M. Kirizawa, \& M.M.R.F. Melo (orgs.). Patrimônio da Reserva Biológica do Alto da Serra de Paranapiacaba. A antiga Estação Biológica do Alto da Serra. São Paulo, Instituto de Botânica, pp.105-117.

Vellozo, J.M.A.C. 1827. Flora Fluminensis ícones tab 116. Paris, J. Knecht.

Vellozo, J.M.A.C. 1881. Dioscorea. Florae Fluminensis. Arquivos do Museu Nacional do Rio de Janeiro 5: $125-126$.

Xifreda, C.C. 1989. Estudios en Dioscoreaceae V. Rehabilitacion de Dioscorea monadelpha y identificacion de Dioscorea subhastata. Darwiniana 29: 401-404.

Xifreda, C.C. \& Kirizawa, M. 2003. Observaciones morfológicas, nomenclaturales y taxonómicas en Dioscorea monadelpha y D. subhastata (Dioscoreaceae). Darwiniana 41: 207-215. 